\title{
WHY DOES GLOBALIZATION FUEL POPULISM? \\ ECONOMICS, CULTURE, AND THE RISE OF RIGHT-WING POPULISM
}

Dani Rodrik

Working Paper 27526

http://www.nber.org/papers/w27526

\author{
NATIONAL BUREAU OF ECONOMIC RESEARCH \\ 1050 Massachusetts Avenue \\ Cambridge, MA 02138 \\ July 2020
}

This paper has been prepared for the Annual Review of Economics. I am grateful to Phoebe Cai for research assistance and to Gordon Hanson for helpful comments. The views expressed herein are those of the author and do not necessarily reflect the views of the National Bureau of Economic Research.

NBER working papers are circulated for discussion and comment purposes. They have not been peer-reviewed or been subject to the review by the NBER Board of Directors that accompanies official NBER publications.

(C) 2020 by Dani Rodrik. All rights reserved. Short sections of text, not to exceed two paragraphs, may be quoted without explicit permission provided that full credit, including $\odot$ notice, is given to the source. 
Why Does Globalization Fuel Populism?

Economics, Culture, and the Rise of Right-wing Populism

Dani Rodrik

NBER Working Paper No. 27526

July 2020

JEL No. F1,F3,F6

\begin{abstract}
There is compelling evidence that globalization shocks, often working through culture and identity, have played an important role in driving up support for populist movements, particularly of the right-wing kind. I start with an empirical analysis of the 2016 presidential election in the U.S. to show globalization-related attitudinal variables were important correlates of the switch to Trump. I then provide a conceptual framework that identifies four distinct channels through which globalization can stimulate populism, two each on the demand and supply sides of politics, respectively. I evaluate the empirical literature with the help of this framework, discussing trade, financial globalization, and immigration separately. I conclude the paper by discussing some apparently anomalous cases where populists have been against, rather than in favor of trade protection.
\end{abstract}

Dani Rodrik

John F. Kennedy School of Government

Harvard University

79 J.F. Kennedy Street

Cambridge, MA 02138

and NBER

dani_rodrik@harvard.edu 
Why DOES GLOBalization Fuel Populism?

ECONOMICS, CULTURE, AND THE RISE OF RIGHT-WING POPULISM

Dani Rodrik ${ }^{1}$

July 2020

\section{Introduction}

Globalization figures prominently in discussions of populism. Especially in its post-1990s variant -- which might be better called "hyperglobalization -- international economic integration seems to have produced domestic disintegration in many countries, deepening the divide between the winners and losers of exposure to global competition. There is nothing particularly surprising about this from the standpoint of economic theory. Standard trade theory is quite clear about the sharp redistributive effects of free trade and open economy macroeconomics has long grappled with the instability of global financial markets. Economic history is equally suggestive. The high points of globalization in previous eras have also been marked by a populist backlash. ${ }^{2}$

But there are still many open questions. First, what are the mechanisms through which globalization fuels populism? Answering this question requires a more fully fleshed out model of political economy. Second, globalization is not just one thing: we can distinguish among international trade, international finance, and international labor flows specifically. How do each one of these facets of globalization work their way through the political system? Third, globalization is clearly not the only economic shock that creates redistributive effects or economic anxiety - and it may not even be the most important economic force to do so. Why does globalization appear to have an outsized effect on politics compared to, say, technological change or regular business cycles?

Fourth, the populist response so far seems to have taken a mostly right-wing form. On the face of it, this is surprising since left-wing populist movements with their redistributive economic agendas could have been the more obvious beneficiary of economic dislocations. Why have nativist, ethnonationalist populists been instead the ones to take advantage? Fifth, and related to the previous

\footnotetext{
${ }^{1}$ This paper has been prepared for the Annual Review of Economics. I am grateful to Phoebe Cai for research assistance and to Gordon Hanson for helpful comments.

${ }^{2}$ See Rodrik $(1997,2011)$ on the economic and social rifts created by advanced stages of globalization, and Rodrik (2018) for an earlier overview of the relationship between globalization and populism.
} 
question, what about the roles of culture, values, and identities? Could it be that populism is rooted not in economics but in a cultural divide -- social conservatives versus social liberals, traditionalists versus modernists, nationalists versus cosmopolitans, ethnically homogenous dominant communities versus "outsider" minorities of various kinds?

The economics versus culture question has been a source of controversy in discussions of populism. The literature on the economic determinants of populism - globalization in particular - is quite rich, as the studies I will discuss in this paper attest to. On the other side, Sides, Tesler, and Vavreck (2018), Norris and Inglehart (2019), and Margalit (2019), among others, have made strong cases for the culture thesis. In the U.S., the culture argument revolves around the strong undercurrent of racism in American society. In Europe, the argument centers on aversion to Muslim and African immigrants, which has long been the basis of support for far-right parties such as the French National Front.

Some of the disagreement revolves around empirical methods. For example, observational studies tend to favor the economics argument, while survey experiments give greater credence to culture (Naoi 2019). But there is a key conceptual difference at the heart of the matter as well. The relative importance one ascribes to economics versus culture depends crucially on whether we are interested in a question about levels or about changes - whether we ask "why do so many people vote for populist candidate?" or we ask "why did the populist vote share increase so much?" (Margalit 2020). ${ }^{3}$ My focus in this paper, as in much of the economics-centered literature, is on the latter question. Since culture transforms slowly, and a constant cannot explain a change, culture is unlikely to do a good job answering the question in changes form. Economic shocks, such as those related to globalization, are a more likely candidate for the answer.

In any case, I do not aim to resolve the economics versus culture debate here. My goal is more limited. By unpacking globalization and specifying the channels through which its different components work their way into politics, I try to bring greater clarity to the discussion on the contribution globalization has made to the rise of populist politics. There is compelling evidence, from diverse settings, that globalization shocks, often working through culture and identity, have played an important role in driving up support for populist, particularly right-wing populist movements. The argument does

\footnotetext{
${ }^{3}$ Margalit (2019) calls these "outcome" versus "explanatory" significance, but I am not sure if this nomenclature is quite appropriate. The difference has to do more with the kind of outcome we are trying to explain. The level and change in support for populists are both outcomes, and we could be interested in explaining either.
} 
not dismiss the possibility that purely cultural factors too may have been at play as well, and I will briefly discuss some of the historical evidence on immigration in the U.S. that leans that way. While I draw on an extensive literature, this is by no means a survey paper. For a recent survey on the political economy of populism, see Guriev and Papaioannou (2020). The political science literature on the relationship between globalization and the rise of the far right is surveyed by Bornschier (2018).

I start the paper in the next section with an empirical look at the 2016 presidential election in the U.S. I focus on the characteristics of both Trump voters in general and "switchers" - voters who supported Obama in 2012 but voted for Trump in 2016. This relatively unstructured data analysis shows that globalization-related attitudinal variables were important correlates of the switch to Trump, even in survey data. Section 3 then presents a conceptual framework to clarify the various channels through which globalization can stimulate populism. I distinguish here between the demand and supply sides of politics, and the different causal pathways that link globalization shocks to political outcomes. I identify four mechanisms in particular, two each on the demand and supply sides: (a) a direct effect from economic dislocation to demands for anti-elite, redistributive policies; (b) an indirect demand-side effect, through the amplification of cultural and identity divisions; (c) a supply-side effect through political candidates adopting more populist platforms in response to ecoomic shocks; and (d) another supply-side effect through political candidates adopting platforms that deliberately inflame cultural and identity tensions in order to shift voters' attention away from economic issues.

Section 4 reviews the empirical literature with the help of this framework, discussing trade, financial globalization, and immigration separately. The existing literature has focused mostly on the first two channels, with the second two (and especially the last) receiving considerably less attention. Section 5 focuses specifically on the outsized political response to globalization shocks and the reasons why right-wing populists have benefited disproportionately. The answers to these two questions may be related, having to so with the way in which globalization shocks interact with latent cultural divisions. Section 6 concludes the paper with a discussion that reversed the direction of causation and examining some apparent exceptions where populists have been against, rather than in favor of trade protection.

\section{Evidence on the empirical correleates of voting patterns in 2016 U.S. presidential election}

In this section I provide the results of some explaratory data analysis of the 2016 presidential election in the U.S. I focus on two types of voters: Trump voters in general and "switchers," i.e., those who voted for Obama in 2012 and switched to Trump in 2016. I try to answer three questions. First, 
what were the distinguishing characteristics of Trump voters? Second, what were the distinguishing characteristics of switchers? Third, how did the switchers differ from other Obama voters from 2012? The answers to the first two questions are provided in Table 1. The answers to the third question are shown in Table 2, where the sample is restricted to Obama voters in 2012. I make no claim to causal or structural interpretation, to which I will turn in the next section. My objective is to understand the broad correlates of these distinct voting patterns.

I use data from American National Election Studies (2019), which is a representative survey of Americans before and after the 2016 presidential elections. Of the 4,270 individuals in the survey, 1,245 report having voted for Trump in 2016 and 1,728 recall having voted for Obama in 2012. There are 154 respondents in the intersection of these two groups, who constitute the switchers. The survey includes a broad range of demographic and attitudinal questions. Note that the regressions reported below have fewer than 4,270 observations because not all respondents answered all the questions.

As my primary indicator of economic insecurity I use the question "how worried are you about your current financial situation?" The five possible valid responses for this question range from "not at all worried" to "extremely worried." I supplement this measure with views on trade, immigration, and banks to gauge the strength of economic correlates. To measure social identity I use respondents' selfassessment of the social class to which they belong. This is a 4-point measure taking the values $1=$ "lower class," 2="working class," 3="middle class," and 4="upper class."

To measure racial attitudes I use the same index as Sides et al. (2018, appendix to Chap. 8). Sides et al. (2018) combine answers to four questions, gauging agreement/disagreement with the following statements:

- "Over the past few years, Blacks have gotten less than they deserve."

- "Irish, Italian, Jewish, and many other minorities overcame prejudice and worked their way up. Blacks should do the same without any special favors."

- "It's really a matter of some people not trying hard enough; if Blacks would only try harder they could be just as well off as Whites."

- "Generations of slavery and discrimination have created conditions that make it difficult for Blacks to work their way out of the lower class."

The five-fold responses to these questions are averaged to obtain a single indicator of attitude to racial inequality, with a higher value indicating greater hostility to racial equality. 
My benchmark specification is a logit regression with attitudes to racial inequality, social class, and economic insecurity (financial worries) as the main regressors in addition to basic demographic variables (age, gender, race, and education). For each dependent variable, I start with this specification and then add specific regressors related to globalization individually. The latter are binary (0-1) variables meant to capture attitudes towards different aspects of economic globalization. They gauge the respondents' support for (i) trade agreements, (ii) immigration, and (iii) regulation of banks. Note that there are no questions in ANES that gauge views on financial globalization specifically; I use the "bank regulation" variable as a proxy for support for financial globalization. A final, kitchen-sink regression shows the results when all regressors are included.

The first six columns of Table 1 probe characteristics of Trump voters in general. Trump voters were more likely to be white, older, and college-educated (these results are not shown). More germane to our analysis, they were significantly more hostile to racial equality and perceived themselves to be of higher social class. The estimated coefficient on racial attitudes is particularly large: a one-point increase in the index of racial hostility - which theoretically ranges from 1 to 5 - is associated with a 0.28 percentage point increase in the probability of voting for Trump (col. 1). By contrast, economic insecurity does not seem to be associated with a propensity to vote for Trump.

The finding that Trump voters thought of themselves as belonging to upper social classes may seem surprising. But this largely reflects the role played by party identification in shaping voting preferences. When we control for Republican party identification (cols. 2 and 6), the estimated coefficient for social class drops sharply and ceases to be statistically significant. In other words, Republican party identification is a strong correlate of support for Trump, and Republicans tend to be wealthier than Democrats. Note, however, that racial hostility remains significant, although its estimated coefficient becomes smaller (cols. 2 and 6).

The remaining columns examine attitudes towards globalization (cols. 2-5). All three of our measures enter statistically significantly: Trump voters disliked trade agreements and immigration; they were also against bank regulation (presumably in line with the general anti-regulation views of (cols. 25) the Republican party). These indictors remain significant in the kitchen-sink version where they are all entered together (col. 6).

In none of these regressions does economic insecurity (financial worries) enter significantly. This changes when we move from Trump voters in general to switchers from Obama to Trump (cols. 7-12). 
There are two essential differences from the baseline specification: financial worries now becomes statistically significant, and switchers do not identify with the upper social classes. Switchers, in other words, view their economic and social status very differently from, and as much more precarious than run-of-the-mill Republican voters for Trump.

With respect to attitudes towards globalization, there are interesting parallels and differences as well. Switchers are similar to Trump voters insofar as they too dislike trade agreements and immigration (cols. 9-11). ${ }^{4}$ But they are dissimilar in that they view regulation of banks favorably. Hence switchers appear to be against all aspects of globalization - trade, immigration, finance. Economic insecurity remains statistically significant when these globalization indicators are added to the regression. But in the kitchen-sink regression -- with all the regressors included simultaneously -- economic insecurity is no longer significant while the globalization attitudes all retain their statistical significance (col. 12).

Finally, in Table 2 I focus on how switchers differ from other Obama voters. For this purpose, I restrict the sample to those respondents who report having voted for Obama in 2012. I repeat the second set of regressions from Table 1 (cols. 7-12) for this restricted sample.

The baseline regression shows that switchers are both generally more hostile to racial equality and feel greater economic insecurity; they don't seem to differ from other Obama voters in their selfassessed social class (col. 1). They are also significantly more anti-trade and anti-immigration (cols. 3-4). Their views on bank regulation are not distinctive (col. 5). When all indicators are included, trade and immigration attitudes enter significantly while economic insecurity loses statistical significance (col. 6).

These results suggest switchers to Trump are different both from Trump voters and from other Obama voters in identifiable respects related to social identity and views on the economy in particular. They differ from regular Trump voters in that they exhibit greater economic insecurity, do not associate themselves with an upper social class, and look favorably on financial regulation. They differ from others who voted for Obama in 2012 in that they exhibit greater racial hostility, more economic insecurity, and more negative attitudes towards trade agreements and immigration.

\section{A conceptual framework}

\footnotetext{
${ }^{4}$ Note that the magnitude of coefficients in cols. 7-12 cannot be directly compared with those for cols. 1-6, since switchers are a much smaller percentage of the sample than Trump voters.
} 
These empirical results suggest, as a first pass, that the vote for Trump was influenced by perceptions on economic conditions as well as by social and racial attitudes. Anti-globalization views appear to be strongly associated with the decision to vote for Trump instead of Hillary Clinton. But these are merely suggestive empirical associations. Parsing the specific causal relationships between economic and attitudinal variables, on the one hand, and political outcomes, on the other, requires a more fully fleshed-out structural model. In particular, social identities, cultural sensitivities, and racial attitudes may well be endogenous, determined in part by objective economic conditions. Economic conditions, in turn, are shaped by a number of different forces, including globalization shocks. In addition, voters' political preferences may be formed also by narratives and messages ("propaganda") emanating from political parties and leaders. And political leaders may choose to formulate their campaign messages in response to economic conditions as well.

Figure 1 sketches a causal framework that highlights the key causal relationships, emphasizing the mechanisms through which globalization may drive support for populism. I distinguish between the demand and supply sides of politics, allowign a role for political leaders' programs and strategies as well individual voters' preferences. Different types of globalization shocks - trade, immigration, finance enter the system through their impact on economic conditions - economic dislocation, in particular. Economic dislocation, in turn, can influence political outcomes - here, electoral success of populist politicians -- through four different causal pathways. These four cusal explanations are identified as $(A)$, $(B),(C)$, and $(D)$ in Figure 1.

First, and most directly, it can determine voters' preferences for policies and leaders $(A)$. A voter in a region where employment prospects have been adversely affected by a rise in imports may choose to cast his vote for a politician who advocates protectionism and a tougher line against foreign exporters. Second, it may shape voters' preferences indirectly through the effect it has on identity or the salience of certain cultural values $(B)$. Concretely, economic shocks can heighten feelings of insecurity, inducing voters to make sharper distinctions between insiders ("us") and ethnic, religious, or racial outsiders ("them"). They can lead voters to yearn for an earlier era of prosperity and stability, increasing the political salience of traditional cultural values and hierarchies. And to the extent that they generate wider economic and social gaps within a nation, economic shocks may reinforce more local, less encompassing identities. To the extent that such effects operate, political preferences that appear to be driven by cultural values will in fact have deeper, economic roots. 
These two causal pathways operate on the demand side of the political equilibrium. The other two channels work through the supply side. Hence a third possibility is that economic shocks affect the ideology of political candidates or the platforms of competing political parties $(C)$. Even if voters' preferences remain unchanged, they may find themselves confronted with parties or candidates that are more polarized on issues of such as trade protection or immigration. The fourth and final channel is that economic shocks may induce some parties - typically those on the right -- to try to render culture and identity more salient in voters' decisions at the polling booth $(D)$. For example, suppose greater economic inequality results in the loss of median-voter support for a right-wing party. The party may counter by attempting to shift the electoral competition away from economics to issues of identity and culture. If such a strategy is successful, it will appear as if electoral outcomes are driven voters' cultural preferences. But the ultimate determinant will be economics - via party strategies - rather than voters' cultural values per se.

Hence globalization shocks can can feed into support for populism directly $(A)$ as well as indirectly $(B, C, D)$; it can activate supply-side $(C)$ as well as demand-side $(A, B, D)$ causal pathways. A full causal explanation of the rise of populism - and its links to globalization -- would not only have to spearately identify each of one of these channels, but also gauge their importance vis-à-vis all the other causal pathways in Figure 1, including, most crucially, those that originate from cultural or identity determinants that are orthogonal to economic dislocation. This is a tall order. Perhaps not surprisingly, no single piece of empirical work has attempted to provide such a comprehensive analysis. What we have instead are empirical papers that focus on some of the individual pieces of the larger puzzle. Collectively, they paint a consistent picture on the importance of globalization shocks on the demand side, both directly $(A)$ and indirectly $(B)$. Supply-side causal pathways have received less attention than others. In particular, there has been virtually no systematic empirical work on channel $(D)$, even though the informal evidence (discussed in section 5 below) is quite suggestive. And convincing tests of the economics versus culture hypotheses have proved elusive.

\section{Empirical studies}

The empirical literature on determinants of populism is summarized in four separate tables (Tables 3-7). I have organized the literature by the main explanatory category that is the focus of the studies: trade (Table 3), immigration (Table 4), financial globalization (Table 5), economic insecurity (Table 6), and culture and identity (Table 7). Since the present paper hones in on globalization and economic insecurity, I have tried to be comprehensive in those areas, but less so with respect to culture 
and identity. Table 7 on culture and identity should be be viewed as illustrative of the empirical work in this area. For each paper covered, the tables include information on the key explanatory variables, dependent variables, main results, geographical setting and time period for which the study was conducted, and estimation method. Note that some papers focus on more than a single determinant (for example, trade and immigration); in those cases I have listed the papers in one table rather than repeating the reference. Below, I will focus on selected papers to discuss the more salient findings; readers are referred to the tables for a fuller sense of the empirical literature.

(a) Trade

Autor et al.'s (2013) original paper analyzing the local labor market effects of the China trade shock has spawned a small cottage industry of papers using a similar approach to document the political consequences of trade shocks. This paper developed a plausibly exogenous instrument for the increase in imports from China by combining (a) the contemporaneous change in imports from China in eight other developed countries, and (b) the industrial composition of production within commuting zones. Since some commuting zones have more industries exposed to Chinese competition than others, this approach allows an examination of the effects of Chinese imports across different localities. In subequent work, Autor, Dorn, Hanson, and Majlesi (ADHM, 2019) have mapped commuting zone data to congressional districts and established several interesting findings.

First, they document that Chinese import penetration had an impact on political preferences. Localities where the China trade shocks was greater experienced an increase in the market share of Fox News (at the expense of viewership for CNN and MSNBC), stronger conservative beliefs (as measured by Pew Surveys), and greater campaign contributions by both left- and right-leaning donors (relative to moderate donors at the center of the ideaologial spectrum). In the authors' words, "localized economic shocks stemming from rising trade pressure in the 2000s increased the relative demand for conservative media content, support for conservative viewpoints, and campaign contributions by more ideologically extreme donors" (ADHM, 2019). Next, they show that the China trade shock increased the likelihood that GOP legislators would get elected in Congressional elections, especially after 2008 . This is so even though the shock appears to have reduced the GOP vote share somewhat overall; the increase in Republican support in competitive districts more than compensated. When candidates are classified according to political ideology, the biggest winners were those on the farthest right (conservative Republicans). The paper also uncovers an interesting interaction with race. GOP candidates were especially helped by trade shocks in majority White districts, where many Democratic voters switched to 
the Republican candidates. In majority non-white districts, the switch was from moderate to liberal Democrats -- not a net gain for the Democratic party.

ADHM (2019) also show that the China import shock produced a boost for the GOP in the Presidential elections of 2008 and 2016 (relative to 2000). In a particularly interesting side note which builds on the results of this paper, the authors estimate that a reduction of the China trade shock by half between 2000 and 2014 would have produced a majority for the Democrats in 2016 in the key battleground states of Pennsylvania, Wisconsin, and Michigan (instead of a defeat) and would have swept Hillary Clinton to the Oval Office in lieu of Donald Trump (Autor et al., 2017). This is a particularly stark illustration of the electoral consequences of trade, and of trade shocks driving populists into office.

The ADHM China trade shock instrument has been used in a number of other papers looking at the effect of trade on polical preferences. Ballard-Rosa et al. (2017) find that individuals living in relatively diverse regions where the China trade shock was more powerful have more authoritarian values. They interpret this as evidence that economic dislocation shapes political identity by producing "social-norm conformity" among historically dominant groups. This paper is an illustration of causal pathway $B$ in Figure 1. By contrast, the original ADHM paper is largely agnostic on whether trade shocks work directly $(A)$ or through their effects on culture and identity $(B)$.

Another paper that sheds light on the mechanisms through which economic insecurity may drive support for right-wing populists is Cerrato et al. (2018). These authors focus explicitly on the cultural backlash produced by the China trade shock. Interestingly, they argue that the political impact of the ADHM trade shock works primarily through (negative) attitudes towards immigrants and racial/ethnic minorities. Attitudes towards international trade per se do not seem to be affected by Chinese import penetration. One specific finding is indicative of what the authors call the "pure" cultural backlash effect: greater import penetration produces negative sentiment towards Muslims. ${ }^{5}$ Since Muslims are a tiny share of the labor market, it is difficult to provide this finding an alternative, economic interpretation. In terms of Figure 1, channel $(B)$ trumps channel $(A)$. Using text analysis of campaign speeches, Cerrato et al. (2018) also provide evidence of the anti-immigrant and anti-trade shift in Republican party Presidential candidates over 2008-2016, which would be consistent with mechanism $(C)$ being at play as well. The import of these findings is that they suggest the cultural determinants of support for populists highlighted in some studies (e.g., Inglehart and Norris 2016, 2019)

\footnotetext{
${ }^{5}$ In a similar vein, Steiner and Harms (2020) find Chinese import shocks lead respondents in Britain to develop more nationalistic attitudes, but not greater affinity to redistributive economic policies.
} 
may themselves have economic underpinnings. They again illustrate the need for a fully fleshed out structural causal model a la Figure 1.

The ADHM approach has been used in a growing number of studies on Europe as well, demonstrating an apparently causal impact of trade shocks on the rise of the populist right. Chinese import penetration has been linked to increased support for nationalist, far-right parties in empirical analyses covering regions within 15 European countries (Colontane and Stanig, 2018c), Italian municipalities (Barone and Kreuter, 2019), German counties (Dippel et al., 2018), and Franch cantons (Malgouyres, 2017). It is significantly associated with the strength of the pro-Brexit vote in Britain's 2016 referendum (Colontane and Stanig, 2018a). It is also found to lead to lower support for democracy and liberal values in a study of regions covering 15 European nations and to cultural, but not economic concerns, on immigration (Colontane and Stanig, 2018b). This last finding parallels the Cerrato et al. (2018) results for the U.S. ${ }^{6}$

It is somewhat surprising that so many studies covering different European nations have found such strong causal effects from Chinese import penetration to political preferences. Safety nets and labor market protections are much stronger in Europe than in the U.S. Imports from China and other low-cost nations have not figured prominently in political campaigns, as they have in the U.S. While public opposition to trade agreements has been on the rise in Europe, this opposition generally revolves around trade with the U.S. and Canada, specifically the proposed Transatlantic Trade and Investment Partnership (TTIP) and the Canada-Europe Comprehensive Economic and Trade Agreement CETA) (Young, 2019). The apparent fact that the local labor markets effects of Chinese imports have left a measurable political imprint even in Europe is suggestive of an oversized sensitivity to trade shocks, a question I will return to later in the paper.

In view of the appeal of the Autor et al. (2013) instrument, causal studies on the political impact of trade have focused largely on the Chinese trade shock. A notable recent exception is a study by Choi, Kuziemko, Washington, and Wright which applies a similar method to the passage of NAFTA in the U.S. (Choi et al., 2020). These authors develop a measure of localities' ex ante vulnerability to NAFTA based on industrial composition and pre-existing tariff levels. Using an event-study method, they find that

\footnotetext{
${ }^{6}$ As in the U.S., trade shocks seem to have boosted the electoral fortunes of mostly right-wing populist movements in Europe and not the left. One exception is the study by Rommel and Walter (2017), which finds that a measure of offshorability of occupation of European respondents is associated with support for leftist and center-right parties but not right-wing populists.
} 
areas with greater exposure to Mexican exports experienced large employment reductions subsequent to the 1993 completion of the Agreement. These areas also shifted sharply towards the Republican party. Interestingly, prior to NAFTA the counties most exposed to Mexico, mainly in the upper South, tended to vote for the Democratic party. By 2000, these same counties had turned heavily Republican. Choi et al. (2020) use a wide variety of regressors to control for possibly confounding secular trends. They also include Autor et al.'s (2013) China trade shock variable. They note that the NAFTA trade shock preceded the China shock, which came in the 2000s. While many of the same localities were hit by the two shocks, the correlation with NAFTA exposure across commuting zones is low for the raw Chinese import penetration measure (0.17) and higher, but considerably less than one for the instrumented version (0.42).

(b) Immigration and refugees

The relationship between presence of immigrants and support for populism is clearly a contingent one. Large metropolitan areas and highly diverse cities such as NYC and London with a large immigrant footprint are not where populists get their votes. In Germany, electoral support for the antiimmigrant AfD is concentrated in the eastern part of the country where there are few immigrants. The identity of source countries, recent changes in the volume of immigration, and spatial patterns of immigrant presence can be more important than the numbers of immigrants per se. In particular, a political backlash on account of either economics or culture seems more likely when there is a rapid increase in foreign presence, when immigrants are low-skilled and come from countries with different racial, ethnic or religious characteristics, and when there is a high level of spatial segregation. ${ }^{7}$ The empirical studies summarized in Table 4 are generally consistent with these ideas. While these studies cover a large number of countries and time periods, the majority are drawn from Europe, which has experienced a recent wave of increase in low-skilled migrants from Muslim and African countries or from East European countries that recently acceded to the EU. The general message that comes out of the table is that this influx has been a boon to right-wing, anti-immigrant parties in Europe. The evidence on the U.S., by contrast, is decidedly mixed (Mayda et al, 2019; Hill et al., 2019).

What are the specific mechanisms through which immigration generates political consequences? Figure 1 suggests a number of possibilities. Consider the following three mechanisms in particular. First, a sudden influx of foreigners may generate a cultural backlash that has nothing to do

\footnotetext{
${ }^{7}$ On the importance of geography and spatial segregation, see Enos (2017).
} 
with economics. This would be the case of xenophobia or anti-immigrant sentiment that arises purely out of psychological and identity-related processes: "we dislike and reject foreigners because they are not like 'us'." Analysts who give culture a primary independent role in driving populism have this mechanism in mind (e.g., Margalit, 2019). Alternatively, the influx may generate a backlash because it creates economic dislocations. Such dislocations arise from competition in local labor markets or in public-goods provision. Immigrants, especially of the low-skill type, can drive local wages down. They can reduce the availability of government services such as public housing or social transfers to nativeborn citizens. As Figure 1 shows, these economic factors can in turn play out politically in two different ways -- either directly, or indirectly through culture and identity. These are variants $(A)$ and $(B)$, respectively. The direct channel refers to the case where political support for populist, anti-immigrant parties increases because these parties allay the economic anxieties of voters $(A)$. The indirect channel refers to the case where economic dislocation activates affirmation of traditional, dominant identities and triggers hostility towards perceived out-groups on cultural grounds $(B)$. In the latter case, antiimmigrant preferences appear to be driven by culture, but the roots are in economics. These two cases provide the other two possible mechanisms, in addition to the purely cultural case. ${ }^{8}$

The empirical literature on the political consequences of immigration has generally not scrutinized these different channels separately. The vast majority of studies summarized in Table 4 focus directly on a "reduced form" relationship between immigrant/refugee presence and voting for populist parties (mostly of the extreme right). For example, Becker et al. (2016) find that the increase in immigrants from 12 recent EU accession countries is associated positively with a vote in favor of Brexit across British localities, though the level of migrants is negatively (and insignificantly) correlated with the Brexit vote. Dustmann et al. (2016) and Dinas et al. (2019) find that an increase in the local concentration of refugees increases support for far-right, anti-immigrant parties, in Denmark and Greece respectively. For the U.S., Mayda et al. (2019) find that an increase in low-skilled immigrants increases the Republican vote share, while an increase in high-skilled immigrants decreases it. Historical evidence, also for the U.S., suggests the association between immigrant influx and support for populist politicians is not a recent phenomenon (Eichengreen et al., 2017, and Tabellini, 2019).

\footnotetext{
${ }^{8}$ Figure 1 contains other possibilities, on the supply side, which I ignore for the moment. An increase in immigration can also alter party platforms $(C)$ and induce political candidates to "prime" racial/ethnic/religious identities. I will return to this channel in a later section of the paper.
} 
The study by Tabellini (2019) is notable because it is one of the few that explicitly tries to unpack the economic versus cultural roots of the anti-immigrant backlash. Tabellini looks at U.S. cities between 1910 and 1930, a period when immigrant levels were very high and anti-immigrant legislation began to be implemented. He uses a shift-share instrument that predicts each city's number of immigrants by interacting 1900 numbers with subsequent (total) migration flows from each sending region, net of the individuals that settled in that city. ${ }^{9}$ The regressions include city fixed effects, so that the results are estimated from changes in immigrant numbers within cities, compared to other cities. Tabellini shows that greater immigration was associated with the election of more conservative representatives and loss of support for the Democratic party (the more pro-immigration party). He finds no evidence that immigration had adverse labor market effects. In fact, more immigration was associated with higher employment levels, even in occupations where immigrants provided greatest competition, and also with greater occupational upgrading (a proxy for wages). Tabellini reasons that the positive employment effects may have been due to this being a period of rapid economic expansion in the U.S., with labor shortages an important constraint on economic activity. Furthermore, the political reaction seems to have been directed primarily at Catholics and Jews, even though these groups' economic impact would have been no different than in the case of immigrants from Protestant countries. Tabellini concludes that the political backlash was rooted not in economic dislocation - i.e., neither in channel $(A)$ nor in $(B)$ - but in purely cultural factors.

Recall that one of the mechanisms through which globalization shocks can influence political outcomes is the effect on politicians' programs (causal pathway $(C)$ ). An interesting paper by Moriconi et al. (2019) focuses in part on this channel. Using the Manifesto Project Database, the paper quantifies each European political party's attitude towards redistribution through the welfare state. The authors find that an increase in less-skilled immigration results in national party platforms to shift towards less redistribution, while high-skilled immigration has the opposite (but statistically insignificant) effect. Since this paper does not focus on populist outcomes per se, it is not included in Table 4. But an earlier paper by the same authors shows that different types of immigration have opposite-signed effects on nationalist sentiments as well: low-skill immigration strengthens nationalism, while high-skill immigration weakens it (Moriconi et al., 2018).

\section{(c) Financial globalization}

\footnotetext{
${ }^{9}$ Tabellini performs a number of checks to control against threats to his instrument's validity -- early immigrant numbers may predict subsequent political outcomes.
} 
Unlike trade and immigration, financial globalization has not received much attention in popular discussions as a source of the populist backlash. This is surprising in some ways. The free flow of shortterm finance across national borders and the buildup of significant foreign liabilities have played a significant role in triggering the financial crisis of 2008-2009, which was the most severe economic shock experienced by advanced nations since the Great Depression of the 1930s until the more recent COVID19 pandemic. The fiscal austerity that deepened and lengthened the employment impact of the crisis, particularly in Europe, was the result of conducting economic policy according to the perceived requirements of financial markets. Yet there has not been much apparent political reaction against financial globalization. Global banks and financial speculators have not become targets in the way Chinese exports or Mexican and muslim immigrants have. This stands in sharp contrast to the original wave of populism in late $19^{\text {th }}$ century U.S., during which the Northestern financial establishment drew much ire as the upholders of the Gold Standard and hard money.

The scholarly empirical literature on the relationship between financial crises/globalization and populism is correspondingly thin, and disproportionately historical (Table 5). Funke et al. (2016) look at the electoral consequences of financial crises in 20 developed countries since 1870. They find that financial crises increase the vote share of far-right parties (but not far-left parties) by around 4 percentage points on average (a 30\% increase) and that the results are statistically stronger for the postWorld War II period. Interestingly, regular business-cycle recessions or macro shocks that do not involve financial crisis do not produce similar effects. Doerr et al. (2019) focus more narrowly on Germany during the 1930s and show that exposure to bank failures increased support for the Nazi party, with localities with a history of anti-Semitism showing larger effects.

Two other papers cover the interesting recent cases of Hungary and Poland. These Eastern European countries are intriguing because they were not subject to the kind of trade and immigration shocks experienced by the U.S. and Western Europe. Yet, they have experienced similar electoral gains by right-wing ethno-nationalist populist movements. These papers suggest external financial shocks may have played a more prominent role there. Gyöngyösi and Verner (2020) study the rise of the far-right Jobbik party in Hungary after the financial crisis of 2008. Many Hungarian households had borrowed in foreign currencies (primarily the Swiss franc). The sharp depreciation of the Hungarian forint after the crisis left these borrowers in severe distress. Gyöngyösi and Verner (2020) show that the far-right populist vote increased especially strongly in localities where foreign currency debt exposure was 
higher, with this financial channel accounting for as much as 20 percent of the increase in the far-right vote.

Ahlquist et al. (2018) carry out an analysis similar in spirit for the Polish parliemantary elections of 2015, which brought the rightwing populist party PiS to power. These elections followed the Swiss National Bank's decision to allow the Swiss Franc to appreciate. This meant a large and unexpected adverse financial shock to Polish borrowers who had taken out low-interest rate mortgages denominated in Swiss Francs. Using a survey carried out just before the elections, Ahlquist et al. (2018) study Polish voters' policy preferences. They document that those exposed to the shock were more likely to demand government action that would make banks pay a larger share of the cost. Among former government voters, Swiss Franc borrowers were more likely to desert the government and vote for PiS. As the authors also make clear, the PiS actively courted these voters by broadening its nationalist, anti-immigrant platform to include policies that would shift the cost of the Zloty depreciation to the banks and protect the borrowers - proposals designed to appeal to the economic interests of the affected voters. So this case appears to be an example of both channel $(A)$ and channel (C) in operation.

\section{(d) Economic insecurity in general}

Whether they take the form of increased import penetration, influx of immigrants, or financial crises, globalization shocks can cause significant economic distress in various segments of the population. But they are are certainly not the only source of economic dislocation. As a cause of job loss, income volatility, and economic insecurity in general, their role is easily dwarfed by other cyclical and secular economic movements. Automation, deindustrialization, de-unionization, flexibilization of labor markets, rising economic inequality, the expansion of the gig economy, expansion of part-time work, spatial concentration of productive economic activities have all loomed large in labor markets in recent decades. In general, these trends have produced greater economic anxiety and a squeeze of middleclass livelihoods (see Center for American Progress, 2014, on the U.S., and Eurofound, 2017, on Europe). ${ }^{10}$ Globalization is related of course to many of these trends, but it is far from the only cause. Table 6 summarizes empirical papers that focus on different sources and aspects of economic insecurity without emphasizing globalization specifically.

\footnotetext{
${ }^{10}$ Economic insecurity can be hard to disentangle from anxiety with regard to loss of social status. See however Gidron and Hall (2017) and Kurer (2020).
} 
Some of the studies in Table 6 take as their independent variable unemployment or declines in incomes, without scrutinizing what may lie behind. But two types of non-globalization shocks in labor markets merit particular mention: automation and labor market de-regulation.

On automation, Anelli, Colantone, and Stanig (2019) study 14 West European nations between 1993 and 2016, looking at individual or regional exposure to automation (instrumented by robot adoption in other countries) based on ex ante industrial structure or occupation. They find greater exposure to robots increases support for right-wing populist parties, both among individuals and across regions. They report that these results are robust to controlling separately for a wide set of cultural values at the individual level (though, as they point out, these attitudinal variable are arguably "posttreatment" indicators, influenced by labor market shocks). Interestingly, they also include the Autor et al. (2017) China trade shock variable, which they find has a small and statistically insignificant effect on the rightward political shift. They attribute the result on trade to be due to the fact that the present study covers a later period than the earlier Colantane and Stanig (2018b) paper, which found a large effect for an almost identical sample of countries. ${ }^{11}$

Dal Bó et al. (2019) focus on the rise of the far-right Sweden Democrats. The authors hone in on the reforms of labor market and welfare state arrangements in 2006 alongside the economic insecurity generated by the financial crisis. These reforms produced greater inequality in Sweden and a deeper divide between labor market insiders who benefited from stable, well-paying jobs and outsiders with stagnant incomes and unpredictable employment opportunities. The paper finds that support for Sweden Democrats correlates strongly, across and within municipalities, with the presence of losers from the reforms and from the financial crisis. Interestingly, and in contrast to many other studies cited earlier, this paper does not find any direct correlation between patterns of local immigration and support for the far right. The authors note, however, that labor market reforms made outsider, antiimmigration voters shift towards Sweden Democrats. As they summarize the results, "our results rhyme well with the idea that an economic shock which creates insecurity may interact with pre-existing, latent, traits among some voters, and lead them to switch their political allegiance." In other words, channel $(B)$ seems to operate alongside channel $(A)$.

\footnotetext{
${ }^{11}$ The Anelli et al. (2019) study covers a more recent period in which the China shock had dissipated somewhat and the financial crisis and austerity policies had a much larger footprint. The authors report that when they restrict their time coverage to the pre-crisis period, they recover a strong China trade shock effect, while automation retains its significance. Caselli et al. (2020) also find that China trade shock does not have a significant effect on vote shares for far-right parties in Italy after 2008.
} 
This paper is also one of the few to make an explicit distinction between the demand-and supply sides of politics (along with Guiso et al., 2018, and Rodrik, 2018) in accounting for the rise of populists. The authors find that politicians from the Sweden Democrats are more likely to be drawn from "outsiders and vulnerable insiders" compared to other parties. To recall Figure 1 , this is another instance of economic shocks driving the supply-side of politics (causal pathway $(C)$ ). They speculate that this might be the reason it has been the extreme right rather than the left that has been able to capitalize on labor market dislocation.

\section{Globalization and economics as cultural flash points}

The rich empirical literature I have discussed in the previous section raises two questions. First, why does globalization elicit such an outsized political backlash, when it is just one of the forces that have buffeted labor markets the macro economy in recent decades? As I have noted, technological change, de-industrialization, and the usual churn of firm contraction and closure impart a much stronger footprint on labor markets than trade or immigration. Yet, empirical evidence leaves no doubt that globalization has played a significant role in the rise of populism in recent years. Second, why has the political backlash taken a largely right-wing, nativist form? The studies I have discussed find that the backlash has overwhelmingly benefited right-wing populists. Left-wing populists who may have been programmatically better positioned to take advantage of the labor market shocks, with their redistributionist agendas, do not seem to have been much advantaged.

The two questions may be related. As many studies note, globalization shocks play on latent cultural and identity divisions in society, both activating and magnifying them. Trade, immigration and financial shocks present obvious "outsider" targets: foreign exporters, culturally different workers, international banks. Economic anxieties and insecurities threats can be recast as threats on the dominant group's traditional way of life, deepening the divide between "us" and "them." This can be a particularly potent channel if the regions of the country or segments of the labor market adversely affected by globalization are less diverse and culturally homogenous, where traditional identities and cultural values were strong to begin with. In terms of Figure 1, this argument suggests the indirect channel $(B)$ may be quite powerful, stronger even than the direct channel $(A)$.

Consider first some direct evidence on the outsized response to globalization shocks. Di Tella and I carried out an online survey where we provided respondents with what looked like a newspaper story on a planned factory closure in a fictitious local community (di Tella and Rodrik, 2020). All of our 
subjects (except those in the control group) were told 900 jobs were at risk. But they were separated into distinct treatment groups with different explanations for why the factory may close. One group was told the factory closure was due to automation (technology shock). The second group was told there had been a shift in consumer preferences away from the products manufactured in the plant (demand shift). A third was told the problem was due to management failure (bad management). Finally, the other treatment groups were told the factory may close because of outsourcing to a foreign country. All respondents were then asked whether they thought the government should do anything in response, and if yes, whether they favored transfers to those who become unemployed (compensation) or import protection.

Figure 2 summarizes the results. First note that both technology and demand shocks elicit a protectionist response of 5 percentage points or so. The increase in desired compensation is of the same order of magnitude, if somewhat smaller. Bad management, by contrast, elicits a demand for transders to workers, but not a statistically significant protectionist response. This stands to reason insofar as respondents want to assist workers but not managers and owners when the fault lies with the latter. What really stands out in the chart, however, is the magnitude of the protectionist repsonse when subjects are told the reason for the prospective plant closure is international trade. The last two treatments in the chart differ by one word only. In one case subjects are told the outsourcing is to France; in the other case, they are told it is to Cambodia. The percentage of respondents who ask for import protection more than doubles in the first case (France), compared to the technology and demand shocks. It quadruples in the second case (Cambodia). And the demand for transfers falls in both cases. Not only is the demand for trade protection highly elastic with respect to negative trade shocks, respondents apparently treat trade with advanced nations very differently than trade with developing nations.

Consider why there is such a big difference in the way that our subjects approach trade with France versus trade with Cambodia. From an en economic-utilitarian perspective, we might have expected respondents to look more favorably on imports from a developing nation. A poorer nation stands to lose more from cutoffs in market access to the U.S. Therefore, a utilitarian calculus would have produced a greater willingness to restrict imports from the richer nation. A cultural-differences perspective, however, yields a different answer. Our American respondents might have thought of Cambodians as much less "like us" than the French, and less worthy of sympathy. They would then have exhibited a greater willingness to penalize them. The results we obtained suggest strongly that the 
cultural perspective was the dominant one among our respondents. Furthermore, when we divided our sample (in the pre-treatment phase of the experiment) between subjects who had favored Trump in the 2016 presidential elections and subjects who had favored Hillary Clinton, we found that the additional protectionist boost in the case of Cambodia was concentrated among those who favored Trump (di Tella and Rodrik, 2020, Table 5). In other words, what was presumably a cultural aversion to Cambodia was magnified among those respondents who were already likely to be more intolerant of cultural differences.

Labor market shocks that drive a greater wedge between winners and losers can inflame latent cultural tensions. Grossman and Helpman (2019) develop a model that describes one possible mechanism. In their model, cultural associations of lower-skill individuals are driven by two conflicting forces. On the one hand, they benefit from identifying with "the nation as a whole," a category which includes the high-skilled individuals with higher social status. On the other hand, they pay a cognitivedissonance cost to the extent their material circumstances differ from the average member of the national aggreate. A trade shock such as greater Chinese import penetration increase the latter cost by geneating a bigger earnings gap between skill groups. That in turn can induce a change in social and cultural identification patterns whereby lower-skill individuals no longer view themselves as members of the nation as a whole, but as members of a narrower group. When racial or ethnic chanracteristics are also associated with group identities, this segmentation of identities can also exhibit itself in cultural terms.

Willkinson (2019) provides an interesting account of how spatial sorting may serve to reinforce the interaction between economics and values to produce a populist backlash. Less educated, socially conservative whites have had lower propensity to migrate to urban areas. Meanwhile, globalization, technological change, and other economic trends have disproportionally benefited urban areas, in particular mega-cities. The China trade shock in particular has hit smaller urban areas and white middleclass communities particularly hard. In Wilkinson's words, "rural stagnation is widening the already significant gap in cultural and moral values produced by the increasing spatial separation of urbanizers and rooted holdouts" (Wilkinson, 2019, 6) This kind of spatial segregation is particularly conducive to generating distrust and magnifying aversion to cultural outsiders (Enos, 2017). Hence economic adversity that exacerbates a pre-existing cultural divide can turn into a powerful force for right-wing populist to leverage in the political sphere. While Wilkinson's story focuses on the U.S., it is clear that Europe shares similar features as well. Spatial segregation between liberals in urban centers and socially 
conservative residents of outlying areas has clearly added fuel to the populist backlash (see also Norris and Inglehart, 2019).

Such effects can be amplified through dynamic feedback loops. If globalization shocks make identity more salient and the result is party platforms that reduce transfers to the poor (both whites and minorities), then the increased economic insecurity of poor whites may increase their aversion to minorities and intensify their desire to cut transfers to them further. This is akin to the mechanism described at length in Arlie Hochschild's ethnographic study of "white anger" in Strangers in their Own Land (Hochschild).

These stories are all demand-side stories (focusing on causal pathway $(B)$ in Figure 1). Economic shocks trigger natural psycho-social processes that alter individual preferences and identities. But economics can inflame culture wars through the supply side as well, by inducing political leaders or parties to adopt campaign strategies deliberately designed to prime latent ethno-religious sensitivites and divides. This is the possibility highlighted by causal pathway $(D)$ in Figure 1.

In Mukand and Rodrik (2018) we provide one possible mechanism. In this model, political entrepreneurs or parties compete for political support by appealing to either voters' economic interests or to voters' ideas, with the latter including ideas about cultural identities or "who they are." One of the results in the paper is that as economic inequality increases in society, a party representing the rich is more likely to invest in strategies that appeal to identity and culture. Greater inequality means the median voter grows more distant from the rich in terms of where she stands on economic policy interests. For the party of the rich, there is now higher return from a political narrative that catalyses identity around issues such as racial resentment, gay marriage, women's rights, and immigration, all of which can give low-income voters a reason to vote against their purely material interests.

Hacker and Pierson (2020) argue that this is exactly the strategy the Republican Party has pursued as U.S. inequality began to rise after the 1970s. The puzzle they address is how the Party was able to advance a right-wing policy agenda - tax reduction, deregulation, weakening of labor market protections, cuts in social insurance - that benefited the wealty and was increasingly unpopular on its own terms. The answer is that the Party adopted a racially charged narrative to enhance the appeal of regressive policies to middle- and lower-middle class white voters. Hacker and Pierson (2020) cite an 
interview in which Republican political operative Lee Atwater lays out the strategy explicitly. ${ }^{12}$ Republicans must use language that is a "lot more" abstract than using the n-word, Atwater told the interviewer. Policies that benefited the rich had to be packaged in terms that would resonate with poorer, white voters. For example, "we want to cut this" would convey "blacks get hurt worse than whites" (Hacker and Pierson, 2020, 112). As Hacker and Pierson put it, "Republicans used white identity to defend wealth inequality." Their account makes clear that America's version of right-wing populism predates Trump. ${ }^{13}$

\section{Concluding remarks: is populism always at odds with globalization?}

This paper has focused on the causal links between globalization and other economic shocks, on the one hand, and the rise of populism, on the other. Before closing, it is worth spending a moment on the reverse linkage, from populism to globalization. The present-day literature takes it as almost axiomatic that populists are against globalization. And to the extent that globalization, in its many facets, is a driver of globalization, this seems like a sensible presumption. But when we disaggregate the two concepts, we can see some interesting departures from received wisdom.

British proponents of Brexit are normally classified with other populists. And in their opposition to immigration, they shared a common bugaboo with populists in other nations. But they were also, at least nominally, free traders. One of the arguments put forth by "Economists for Brexit" (2016) was that the EU was a protectionist bloc, maintaining high barriers to protect its agriculture and manufacturing. They argued Brexit would enable Britain to reduce those barriers and reap significantly larger gains by trading at world market prices. What the Brexiteers opposed first and foremost was the European Union and the supranational rules emanating from it. Restoring national democratic sovereigny over economic policy would allow Britain to devise its own rules, which in the case of trade, were expected to be more liberal.

The Brexit case illustrates the general principle that populists are not always and necessarily protectionist. What they oppose are the elites - domestic or foreign - that they claim over-ride the

\footnotetext{
${ }^{12}$ Atwater was promised lifetime anonymity for his comments, which came into the public domain after his untimely death in 1991.

${ }^{13}$ As Hopkins (2019) points out, Trump's presidential campaign contained strong undertones of anti-Latino priming as well. Yet Hopkins (2019) finds anti-Latino prejudice was not strongly predictive of the shift to Trump, while antiBlack prejudice was a strong predictor. Another indication that party strategies to prime ethnic divisions may not always be successful comes from Schwartz et al. (2020), who report that anti-immigrant and anti-refugee sentiments among their sample of UK respondents actually softened after the Brexit referendum.
} 
popular will at home. Their views on the globalization are often mediated through the relationship of those elites to the international economy.

A second case in point is the U.S. populist movement during the late $19^{\text {th }}$ century. The movement arose out of the plight of farmers in the Southern and Western parts of the country who were being squeezed by decline in agriculture prices, on the one hand, and high debt burdens, on the other. The Gold Standard was seen as responsible, since it kept credit conditions tight and prevented an increase in the money supply. The People's Party's ire was directed at the supporters of the Gold Standard, Notheastern bankers and the financial elite. William Jennings Bryan's famous rallying cry of 1896 is a ringing statement of populists' hostility to the financial globalization of their day: "You shall not crucify mankind upon a cross of gold."

Late $19^{\text {th }}$ century American populists may have been against bankers and global finance, but they also opposed tariffs. The U.S. had at the time quite high import tariffs, due to the Civil War tariffs that were further raised by the McKinley tariff of 1890. Republicans generally favored high tariffs, which they viewed as important for developing American industry. Democrats and Populists thought import tariffs were a regresive tax that hurt ordinary people and benefited mainly the Northeastern industrial classes (Irwin 2017, 244ff). Populists sought to replace the tariff with a progressive income tax instead (Mehrotra, 2002,178). As one labor advocate put it at the time, the import tariff was

devised to draw the money from the working people chiefly, and then to cover up the amount so taken, that they might be squeezed without knowing it. It was seen that if a man should be taxed ten dollars for the privilege of wearing an overcoat, he would rebel against such an outrage, but if, by any hocus-pocus, he could be prevailed on to buy the garment, with the tax added to its original cost, he would not suspect the extent of his robbery.... (quoted in Mehrotra, 2002, 183)

Hence American populists of an earlier era had a much more sound understanding of the workings of import tariffs than many apparently do today. Populists lost this particular battle, and their crusade against the Gold Standard did not bear fruit either. But their ideas were long-lived. Income taxation became a permanent fixture of the U.S. economy after the passage of a constitutional amendment in 1913. Franklin D. Roosevelt took the country out of the Gold Standard eventually in 1933.

Populists in late $19^{\text {th }}$ century America wanted freer trade because they believed protection helped the country's elites and hurt ordinary people. Today's populists want protection for the same 
reason, namely that globalization benefits the rich and wealthy but harms the middle class. There are of course many differences between the People Party back then and Trumpist Republicans today. But in terms of attitudes towards globalization, what has changed in the meantime is not the nature of populism, but the relationship of the American elite to the world economy. 


\section{REFERENCES}

Ahlquist, John, Mark Copelovitch, and Stefanie Walter. "The Political Consequences of External Economic Shocks: Evidence from Poland." American Journal of Political Science, 2020. https://doi.org/10.1111/aips.12503.

Algan, Yann, Sergei Guriev, Elias Papaioannou, and Evgenia Passari. "The European Trust Crisis and the Rise of Populism." Brookings Papers on Economic Activity, 2017, 309.

American National Election Studies. User's Guide and Codebook for the ANES 2016 Time Series Study. University of Michigan and Stanford University, 2019.

Anelli, Massimo, Italo Colantone, and Piero Stanig. "We Were the Robots: Automation and Voting Behavior in Western Europe." SSRN Electronic Journal, 2019. https://doi.org/10.2139/ssrn.3419966.

Autor, David, David Dorn, Gordon Hanson, and Kaveh Majlesi. "A Note on the Effect of Rising Trade Exposure on the 2016 Presidential Election." Appendix to Autor, Dorn, Hanson, and Majlesi, "Importing Political Polarization? The Electoral Consequences of Rising Trade Exposure," 2017.

- - . "Importing Political Polarization? The Electoral Consequences of Rising Trade Exposure," 2020.

Autor, David H., David Dorn, and Gordon H. Hanson. "The China Syndrome: Local Labor Market Effects of Import Competition in the United States." American Economic Review 103, no. 6 (2013): 21212168. https://doi.org/10.1257/aer.103.6.2121.

Ballard-Rosa, Cameron, Amalie Jensen, and Kenneth Scheve. "Economic Decline, Social Identity, and Authoritarian Values in the United States," March 2019.

Barone, Guglielmo, Alessio D'Ignazio, Guido de Blasio, and Paolo Naticchioni. "Mr. Rossi, Mr. Hu and Politics: The Role of Immigration in Shaping Natives' Voting Behavior." Journal of Public Economics 136 (2016): 1-13.

Barone, Guglielmo, and Helena Kreuter. "Low-Wage Import Competition and Populist Backlash: The Case of Italy." Working Paper. FiFo Discussion Paper, 2019. https://www.econstor.eu/handle/10419/210375.

Becker, Sascha O, and Thiemo Fetzer. "Did Eastern European Immigration Cause an Increase in AntiEuropean Sentiment in the UK?," August 22, 2017, 77.

Becker, Sascha O., Thiemo Fetzer, and Dennis Novy. "Who Voted for Brexit? A Comprehensive DistrictLevel Analysis." Economic Policy 32, no. 92 (2017): 601-650. https://doi.org/10.1093/epolic/eix012.

Bergh, Andreas, and Anders Gustafsson. "Globalization and Populism in Europe." SSRN Electronic Journal, 2019. https://doi.org/10.2139/ssrn.3489924.

Bornschier, Simon, "Globalization, Cleavages and the Radical Right," in Jens Rydgren, ed., The Oxford Handbook of the Radical Right, Oxford University Press, 2018.

Bromhead, Alan de, Barry Eichengreen, and Kevin H. O'Rourke. "Political Extremism in the 1920s and 1930s: Do German Lessons Generalize?" The Journal of Economic History 73, no. 2 (June 2013): 371-406. https://doi.org/10.1017/S0022050713000302. 
Brunner, Beatrice, and Andreas Kuhn. "Immigration, Cultural Distance and Natives' Attitudes Towards Immigrants: Evidence from Swiss Voting Results." Kyklos 71, no. 1 (2018): 28-58.

https://doi.org/10.1111/kykl.12161.

Caselli, Mauro, Andrea Fracasso, and Silvio Traverso, "Globalization, Robotization and Electoral Outcomes: Evidence from Spatial Regressions for Italy, Journal of Regional Science, 2020, forthcoming.

Center for American Progress, "The Middle-Class Squeeze: A Picture of Stagnant Incomes, Rising Costs, and What We Can Do to Strengthen America's Middle Class," September 2014. https://cdn.americanprogress.org/wp-content/uploads/2014/09/MiddeClassSqueeze.pdf.

Cerrato, Andrea, Federico Maria Ferrara, and Francesco Ruggieri. "Why Does Import Competition Favor Republicans? Localized Trade Shocks, Voting Behavior, and Scapegoating in the U.S." SSRN Electronic Journal, 2018. https://doi.org/10.2139/ssrn.3147169.

Che, Yi, Yi Lu, Jusin R. Pierce, Peter K. Schott, and Zhigang Tao. "Did Trade Liberalization with China Influence U.S. Elections?," Apirl 2017.

Chen, Shuai. "Unemployment, Immigration, and Populism: Evidence from Two Quasi-Natural Experiments in the United States," 2018.

Choi, Jiwon, Ilyana Kuziemko, Ebonya Washington, and Gavin Wright. "Local Employment and Political Effects of Trade Deals: Evidence from NAFTA," February 2, 2020.

Colantone, Italo, and Piero Stanig. "Global Competition and Brexit." The American Political Science Review 112, no. 2 (2018): 201-218. https://doi.org/10.1017/S0003055417000685.

- - - "The Economic Determinants of the 'Cultural Backlash': Globalization and Attitudes in Western Europe." SSRN Electronic Journal, 2018. https://doi.org/10.2139/ssrn.3267139.

- - . "The Trade Origins of Economic Nationalism: Import Competition and Voting Behavior in Western Europe." American Journal of Political Science 62, no. 4 (2018): 936-953. https://doi.org/10.1111/ajps.12358.

Dal Bó, Ernesto, Frederico Finan, Olle Folke, Torsten Persson, and Johanna Rickne. "Economic Losers and Political Winners: Sweden's Radical Right," February 2019, 64.

Dauth, Wolfgang, Sebastian Findeisen, and Jens Suedekum. "The Rise of the East and the Far East: German Labor Markets and Trade Integration." Journal of the European Economic Association 12, no. 6 (December 1, 2014): 1643-75. https://doi.org/10.1111/jeea.12092.

Di Tella, Rafael, and Dani Rodrik. "Labour Market Shocks and the Demand for Trade Protection: Evidence from Online Surveys." The Economic Journal, 2020. https://doi.org/10.1093/ej/ueaa006.

Dinas, Elias, Konstantinos Matakos, Dimitrios Xefteris, and Dominik Hangartner. "Waking Up the Golden Dawn: Does Exposure to the Refugee Crisis Increase Support for Extreme-Right Parties?" Political Analysis 27, no. 2 (2019): 244-254. https://doi.org/10.1017/pan.2018.48.

Dippel, Christian, Robert Gold, Stephan Heblich, and Rodrigo R. Pinto. "Instrumental Variables and Causal Mechanisms: Unpacking the Effect of Trade on Workers and Voters." CESifo Working Paper Series, no. 6816 (January 17, 2018). https://escholarship.org/uc/item/4kp5c6ji.

Doerr, Sebastian, Stefan Gissler, José-Luis Peydró, and Hans-Joachim Voth. "From Finance to Fascism." Barcelona GSE Working Paper No. 1092, April 2020. 
Dustmann, Christian, Kristine Vasiljeva, and Anna Piil Damm. "Refugee Migration and Electoral Outcomes." The Review of Economic Studies 86, no. 5 (2018): 2035-91.

https://doi.org/10.1093/restud/rdy047.

Economists for Brexit. The Economy after Brexit, 2016. https://www.economistsforfreetrade.com/wpcontent/uploads/2017/08/Economists for Brexit The Economy after Brexit.pdf.

Edo, Anthony, Yvonne Giesing, Jonathan Öztunc, and Panu Poutvaara. "Immigration and Electoral Support for the Far-Left and the Far-Right." European Economic Review 115 (June 2019): 99-143. https://doi.org/10.1016/i.euroecorev.2019.03.001.

Eichengreen, Barry, Michael Haines, Matthew Jaremski, and David Leblang. "Populists at the Polls: Economic Factors in the 1896 Presidential Election." NBER Working Paper Series, 2017, 23932. https://doi.org/10.3386/w23932.

Enke, Benjamin. "Moral Values and Voting," October 11, 2019.

Enos, Ryan D. The Space Between Us: Social Geography and Politics. Cambridge, United Kingdom; New York, NY: Cambridge University Press, 2017.

Eurofound. Income Inequalities and Employment Patterns in Europe before and after the Great Recession. Luxembourg: Publications Office of the European Union, 2017. https://op.europa.eu/en/publication-detail/-/publication/ab252b03-150c-11e7-808e01aa75ed71a1/language-en.

Fetzer, Thiemo. "Did Austerity Cause Brexit?" American Economic Review 109, no. 11 (November 2019): 3849-86. https://doi.org/10.1257/aer.20181164.

Funke, Manuel, Moritz Schularick, and Christoph Trebesch. "Going to Extremes: Politics after Financial Crises, 1870-2014." European Economic Review 88 (2016): 227-260. https://doi.org/10.1016/j.euroecorev.2016.03.006.

Gerdes, Christer, and Eskil Wadensjö. "The Impact of Immigration on Election Outcomes in Danish Municipalities." SULCIS Working Papers. SULCIS Working Papers. Stockholm University, Linnaeus Center for Integration Studies - SULCIS, March 10, 2010. https://ideas.repec.org/p/hhs/sulcis/2010 003.html.

Gibbons, Joseph. "The Space between Us: Social Geography and Politics." Contemporary Sociology: A Journal of Reviews 48, no. 2 (2019): 163-165. https://doi.org/10.1177/0094306119828696i.

Gidron, Noam, and Peter A. Hall. "The Politics of Social Status: Economic and Cultural Roots of the Populist Right." British Journal of Sociology 68, no. S1 (2017): S57-S84. https://doi.org/10.1111/1468-4446.12319.

Raul Gomez, and Luis Ramiro, "Beyond the 2008 Great Recession: Economic Factors and Electoral Support for the Radical Left in Europe," Party Politics, 2017, 1-11.

Guiso, Luigi, Helios Herrera, Massimo Morelli, and Tommaso Sonno. "Populism: Demand and Supply," November 25, 2018.

Guriev, Sergei, and Elias Papaioannou, "The Political Economy of Populism," CEPR Discussion Paper DP14433, February 2020.

Gyöngyösi, Gyozo, and Emil Verner. "Financial Crisis, Creditor-Debtor Conflict, and Populism," February 2020. 
Hacker, Jacob S., and Paul Pierson. Let Them Eat Tweets: How the Right Rules in an Age of Extreme Inequality. New York and London: Liveright Publishing, 2020.

Halla, Martin, Alexander F. Wagner, and Josef Zweimüller. "Immigration and Voting for the Far Right." Journal of the European Economic Association 15, no. 6 (2017): 1341-1385. https://doi.org/10.1093/jeea/jvx003.

Harmon, Nikolaj A. "Immigration, Ethnic Diversity, and Political Outcomes: Evidence from Denmark." The Scandinavian Journal of Economics 120, no. 4 (2018): 1043-74. https://doi.org/10.1111/sjoe.12239.

Hill, Seth J., Daniel J. Hopkins, and Gregory A. Huber, "Local Demographic Changes and US Presidential Voting, 2012 to 2016," PNAS, December 2019. www.pnas.org/cgi/doi/10.1073/pnas.1909202116.

Hobolt, Sara B., and James Tilley. "Fleeing the Centre: The Rise of Challenger Parties in the Aftermath of the Euro Crisis." West European Politics 39, no. 5 (June 16, 2016): 971-91. https://doi.org/10.1080/01402382.2016.1181871.

Hochschild, Arlie Russell, Strangers in Their Own Land: Anger and Mourning on the American Right, The New Press, New York, 2016.

Hopkins, Daniel J., "The Activation of Prejudice and Presidential Voting: Panel Evidence from the 2016 U.S. Election," Political Behavior, online publication, September 2019.

Im, Zhen Jie, Nonna Mayer, Bruno Palier, and Jan Rovny. "The 'Losers of Automation': A Reservoir of Votes for the Radical Right?" Research \& Politics 6, no. 1 (2019). https://doi.org/10.1177/2053168018822395.

Inglehart, Ronald, and Pippa Norris. "Trump, Brexit, and the Rise of Populism: Economic Have-Nots and Cultural Backlash." SSRN Electronic Journal, 2016. https://doi.org/10.2139/ssrn.2818659.

Irwin, Douglas A. Clashing over Commerce: A History of US Trade Policy. Markets and Governments in Economic History. Chicago: The University of Chicago Press, 2017.

Iversen, Torben, David Soskice, and Alice Xu. "Transition to the Knowledge Economy and the Rise of Populism: A Human Capital Perspective," 2017.

Jensen, J. Bradford, Dennis P. Quinn, and Stephen Weymouth. "Winners and Losers in International Trade: The Effects on US Presidential Voting" 71, no. 3 (2017): 423-457. https://doi.org/10.1017/S0020818317000194.

Kurer, Thomas, The Declining Middle, "Occupational Change, Social Status and the Populist Right," Comparative Political Studies, 2020.

Malgouyres, Clement. "Trade Shocks and Far-Right Voting: Evidence from French Presidential Elections." SSRN Electronic Journal, 2017. https://doi.org/10.2139/ssrn.2942173.

Margalit, Yotam. "Costly Jobs: Trade-Related Layoffs, Government Compensation, and Voting in U.S. Elections." American Political Science Review 105, no. 1 (2011): 166-188. https://doi.org/10.1017/S000305541000050X.

- - . "Economic Insecurity and the Causes of Populism, Reconsidered." Journal of Economic Perspectives 33, no. 4 (2019): 152-170. https://doi.org/10.1257/jep.33.4.152.

Mayda, Anna Maria, Giovanni Peri, and Walter Steingress. "The Political Impact of Immigration: Evidence from the United States." American Economic Journal: Applied Economics, February 6, 2019. 
Mehrotra, Ajay K. "'More Mighty than the Waves of the Sea': Toilers, Tariffs, and the Income Tax Movement, 1880-1913." Labor History 45, no. 2 (2004): 165-198.

https://doi.org/10.1080/0023656042000217246.

Mendez, Ildefonso, and Isabel M. Cutillas. "Has Immigration Affected Spanish Presidential Elections Results?" Journal of Population Economics 27, no. 1 (January 2014): 135-71. https://doi.org/10.1007/s00148-013-0471-y.

Mian, Atif, Amir Sufi, and Francesco Trebbi. "Resolving Debt Overhang: Political Constraints in the Aftermath of Financial Crises." American Economic Journal: Macroeconomics 6, no. 2 (2014): 1-28. https://doi.org/10.1257/mac.6.2.1.

Moriconi, Simone, Giovanni Peri, and Riccardo Turati. "Skill of the Immigrants and Vote of the Natives: Immigration and Nationalism in European Elections 2007-2016." NBER Working Paper Series, 2018, 25077. https://doi.org/10.3386/w25077.

Mukand, Sharun, and Dani Rodrik. "The Political Economy of Ideas: On Ideas Versus Interests in Policymaking," March 2018. https://drodrik.scholar.harvard.edu/publications/ideas-versusinterests.

Mutz, Diana C. "Status Threat, Not Economic Hardship, Explains the 2016 Presidential Vote." Proceedings of the National Academy of Sciences of the United States of America 115, no. 19 (2018): E4330-39. https://doi.org/10.1073/pnas.1718155115.

Naoi, Megumi, "Survey Experiments in International Political Economy: What We (Don't) Know About the Backlash Against Globalization," Annual Review of Political Science, 23, 2020, 333-56.

Norris, Pippa, and Ronald Inglehart, Cultural Backlash: Trump, Brexit and Authoritarian Populism, Cambridge University Press, 2019.

Otto, Alkis Henri, and Max Friedrich Steinhardt. "Immigration and Election Outcomes - Evidence from City Districts in Hamburg." Regional Science and Urban Economics 45 (March 2014): 67-79. https://doi.org/10.1016/i.regsciurbeco.2014.01.004.

Rodrik, Dani, Has Globalization Gone Too Far? Institute for International Economics, Washington, D.C., 1997

Rodrik, Dani, The Globalization Paradox: Democracy and the Future of the World Economy, W.W. Norton, 2011.

Rodrik, Dani, "Populism and the Economics of Globalization," Journal of International Business Policy, vol. 1, 2018.

Rommel, Tobias, and Stefanie Walter. "The Electoral Consequences of Offshoring: How the Globalization of Production Shapes Party Preferences." Comparative Political Studies 51, no. 5 (2018): 621-658. https://doi.org/10.1177/0010414017710264.

Rothwell, Jonathan T., and Pablo Diego-Rosell. "Explaining Nationalist Political Views: The Case of Donald Trump." SSRN Electronic Journal, 2016. https://doi.org/10.2139/ssrn.2822059.

Roupakias, Stelios, and Michael Chletsos, "Immigration and Far-Right Voting: Evidence from Greece," The Annals of Regional Science, 2020.

Schwartz, Cassilde, Miranda Simon, David Hudson, and Jennifer van-Heerde-Hudson, "A Populist Paradox? How Brexit Softened Anti-Immigrant Attitudes," British Journal of Political Science, 2020. 
Sides, John, Michael Tesler, and Lynn Vavreck, Identity Crisis: The 2016 Presidential Campaign and the Battle for the Meaning of America, Princeton University Press, 2018.

Steiner, Nils D., and Philipp Harms, "Local Trade Shocks and the Nationalist Backlash in Political Attitudes: Panel Data Evidence from Great Britain," Gutenberg School of Management and Economics, May 2020.

Swank, Duane, and Hans-Georg Betz. "Globalization, the Welfare State and Right-Wing Populism in Western Europe." Socio-Economic Review 1, no. 2 (2003): 215-245. https://doi.org/10.1093/soceco/1.2.215.

Tabellini, Marco. "Gifts of the Immigrants, Woes of the Natives: Lessons from the Age of Mass Migration." The Review of Economic Studies 87, no. 1 (2019): 454-86. https://doi.org/10.1093/restud/rdz027.

Vertier, Paul, and Max Viskanic. “Dismantling the 'Jungle': Migrant Relocation and Extreme Voting in France." SSRN Scholarly Paper. Rochester, NY: Social Science Research Network, January 9, 2019. https://doi.org/10.2139/ssrn.2963641.

Wilkinson, Will. "The Density Divide: Urbanization, Polarization, and Populist Backlash." Washington, D.C.: Niskanen Center, June 2019.

Young, Alasdair R. "Two Wrongs Make a Right? The Politicization of Trade Policy and European Trade Strategy." Journal of European Public Policy 26, no. 12 (2019): 1883-1899. https://doi.org/10.1080/13501763.2019.1678055. 
Figure 1: A causal framework

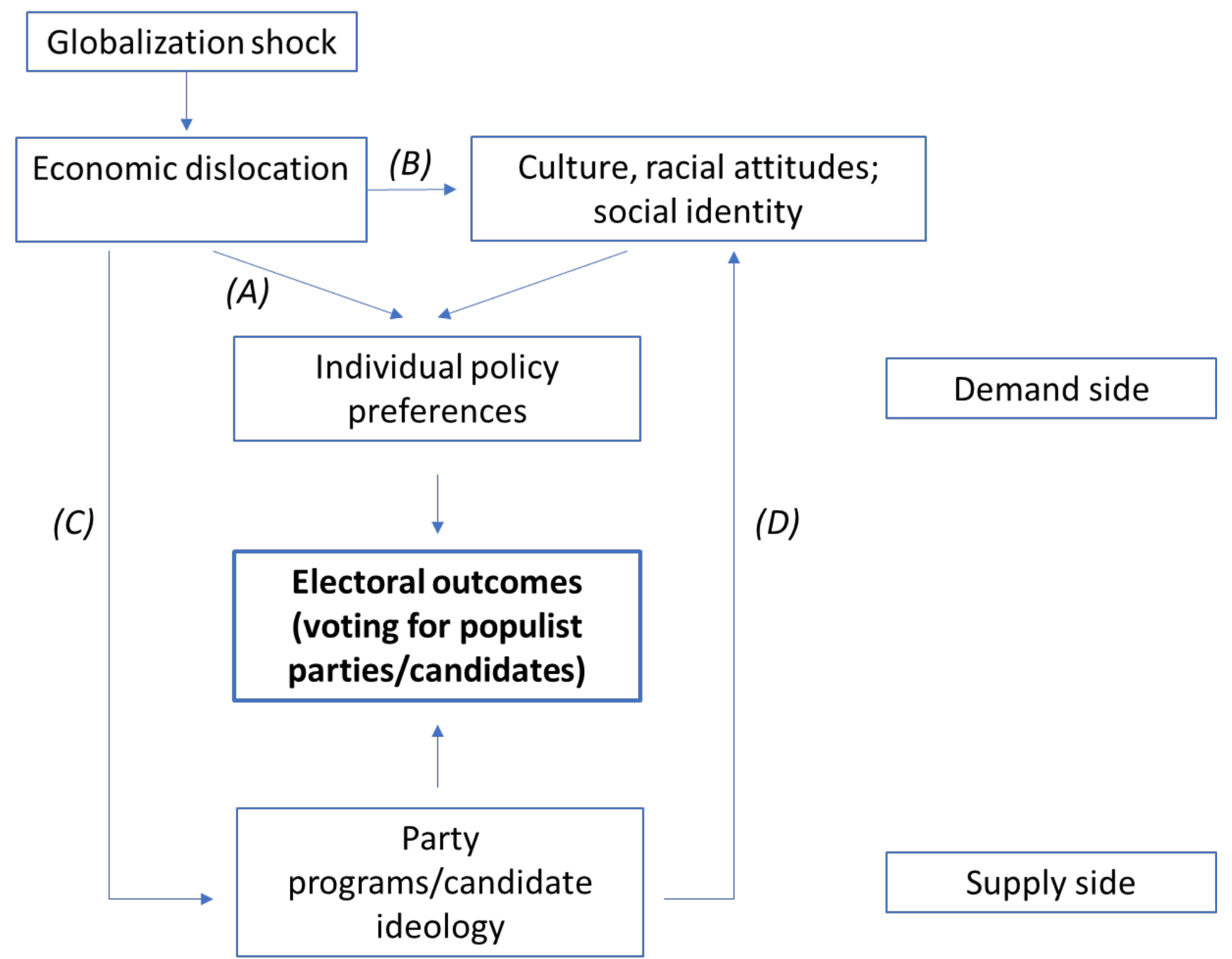

Source: Author 


\section{Figure 2: Preferred responses to labor market displacement shocks}

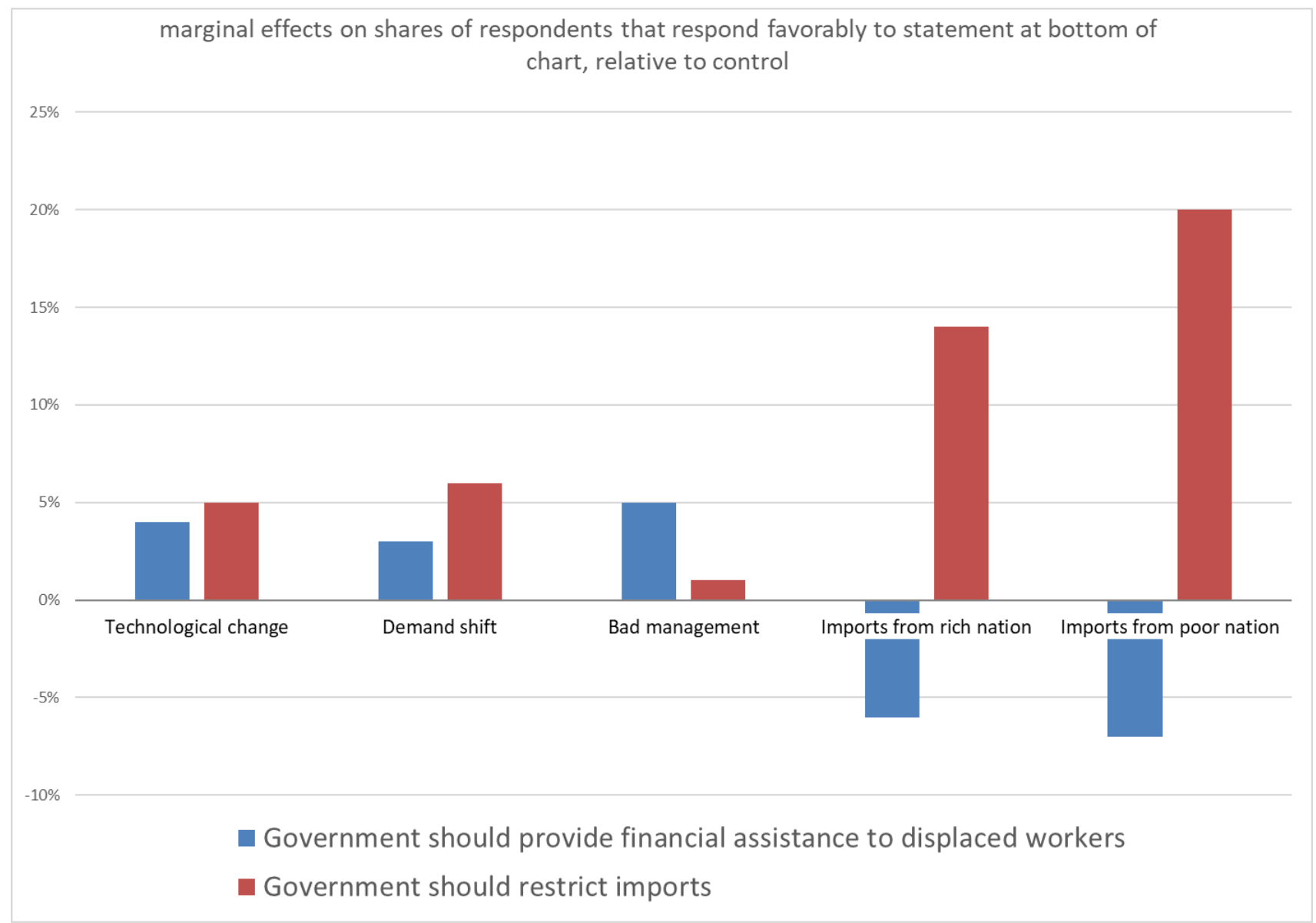

Source: Di Tella and Rodrik (2020) 
Table 1: Correlates of Trump vote in 2016 election

\begin{tabular}{|c|c|c|c|c|c|c|c|c|c|c|c|c|}
\hline & \multicolumn{6}{|c|}{ Dependent variable: vote for Trump (2016) } & \multicolumn{6}{|c|}{ Dependent variable: switch from Obama (2012) to Trump } \\
\hline & $(1)$ & $(2)$ & (3) & $(4)$ & (5) & $(6)$ & (7) & $(8)$ & (9) & $(10)$ & $(11)$ & $(12)$ \\
\hline Racial inequality attitude & $0.282^{*}$ & $0.189^{*}$ & $0.274^{*}$ & $0.246^{*}$ & $0.273^{*}$ & $0.157^{*}$ & $0.026^{*}$ & $0.035^{*}$ & $0.022^{*}$ & $0.021 * *$ & $0.029 *$ & $0.029^{*}$ \\
\hline (5-point scale) & $(0.014)$ & $(0.015)$ & $(0.014)$ & $(0.016)$ & $(0.016)$ & $(0.016)$ & $(0.008)$ & $(0.009)$ & $(0.008)$ & $(0.008)$ & $(0.008)$ & (0.009) \\
\hline Social class, self-reported & $0.044^{*}$ & 0.004 & $0.046^{*}$ & $0.047^{*}$ & $0.043 *$ & 0.013 & -0.007 & -0.004 & -0.005 & -0.007 & -0.007 & -0.001 \\
\hline (4-point scale) & $(0.015)$ & $(0.014)$ & $(0.016)$ & $(0.015)$ & $(0.015)$ & $(0.013)$ & $(0.007)$ & $(0.007)$ & $(0.008)$ & $(0.007)$ & $(0.007)$ & $(0.008)$ \\
\hline Financial worries & -0.003 & 0.005 & -0.003 & -0.013 & 0.001 & 0.000 & $0.011^{* *}$ & $0.010 * *$ & $0.011 * *$ & $0.010 * *$ & $0.010 * *$ & 0.008 \\
\hline (4-point scale) & $(0.008)$ & $(0.007)$ & $(0.008)$ & $(0.008)$ & (0.009) & $(0.007)$ & $(0.005)$ & $(0.005)$ & $(0.005)$ & $(0.005)$ & $(0.005)$ & $(0.005)$ \\
\hline \multirow[t]{2}{*}{ Republican } & & $0.281^{*}$ & & & & $0.254^{*}$ & & $-0.045^{*}$ & & & & $-0.047^{*}$ \\
\hline & & $(0.015)$ & & & & $(0.016)$ & & $(0.015)$ & & & & $(0.015)$ \\
\hline Trade agreements oppose & & & $0.106^{*}$ & & & $0.091^{*}$ & & & $0.029 *$ & & & $0.027 * *$ \\
\hline (binary variable) & & & $(0.024)$ & & & $(0.023)$ & & & $(0.011)$ & & & $(0.011)$ \\
\hline Immigration steals jobs & & & & $0.147^{*}$ & & $0.095^{*}$ & & & & $0.020 * *$ & & $0.023 * *$ \\
\hline (binary variable) & & & & $(0.018)$ & & $(0.016)$ & & & & $(0.010)$ & & $(0.010)$ \\
\hline Bank regulation favor & & & & & $-0.081 *$ & $-0.051^{*}$ & & & & & $0.021 * *$ & $0.018^{* * *}$ \\
\hline (binary variable) & & & & & $(0.20)$ & $(0.018)$ & & & & & $(0.010)$ & $(0.010)$ \\
\hline $\mathrm{N}$ & 2,153 & 2,144 & 2,137 & 2,149 & 2,134 & 2,115 & 2,153 & 2,144 & 2,137 & 2,149 & 2,134 & 2,115 \\
\hline
\end{tabular}

Notes: ANES data. All specifications include age, gender, race (white), and education (high-school or below) as additional regressors.

Estimates and standard errors are generated with logistics regressions using ANES sample weights and clusters. Refer to text for description of variables.

Reported coefficients are average marginal effects. Delta-method standard errors are in parentheses.

Levels of statistical significance: ${ }^{*} 0.01 ; * * 0.05$. 
Table 2: Correlates of switching to Trump in 2016 election among Obama (2012) voters

\begin{tabular}{|c|c|c|c|c|c|c|}
\hline & \multicolumn{6}{|c|}{ Dependent variable: switch from Obama (2012) to Trump } \\
\hline & (1) & (2) & (3) & (4) & (5) & (6) \\
\hline Racial inequality attitude & $0.134^{*}$ & $0.127^{*}$ & $0.125^{*}$ & $0.110^{*}$ & $0.137^{*}$ & $0.102^{*}$ \\
\hline (5-point scale) & $(0.018)$ & $(0.019)$ & $(0.018)$ & $(0.018)$ & $(0.018)$ & $(0.018)$ \\
\hline Social class, self-reported & -0.020 & -0.025 & -0.018 & -0.017 & -0.020 & -0.024 \\
\hline (4-point scale) & $(0.016)$ & $(0.016)$ & $(0.016)$ & $(0.016)$ & $(0.016)$ & $(0.016)$ \\
\hline Financial worries & $0.018^{* *}$ & $0.016 * * *$ & $0.015^{* * *}$ & 0.011 & $0.017 * * *$ & 0.006 \\
\hline (4-point scale) & $(0.009)$ & $(0.009)$ & $(0.009)$ & $(0.008)$ & $(0.009)$ & (0.009) \\
\hline \multirow[t]{2}{*}{ Republican } & & $0.093^{*}$ & & & & $0.096^{*}$ \\
\hline & & $(0.032)$ & & & & $(0.030)$ \\
\hline Trade agreements oppose & & & $0.065^{*}$ & & & $0.054 * *$ \\
\hline (binary variable) & & & $(0.023)$ & & & $(0.021)$ \\
\hline Immigration steals jobs & & & & $0.093^{*}$ & & $0.081 * *$ \\
\hline (binary variable) & & & & $(0.021)$ & & $(0.020)$ \\
\hline Bank regulation favor & & & & & 0.025 & 0.029 \\
\hline (binary variable) & & & & & $(0.24)$ & $(0.024)$ \\
\hline $\mathrm{N}$ & 885 & 884 & 881 & 883 & 878 & 874 \\
\hline
\end{tabular}

Notes: ANES data. Sample is restricted to respondents who report voting for Obama in 2012.

All specifications include age, gender, race (white), and education (high-school or below) as additional regressors. Estimates and standard errors are generated with logistics regressions using ANES sample weights.

Reported coefficients are average marginal effects. Delta-method standard errors are in parentheses. Levels of statistical significance: ${ }^{*} 0.01 ;{ }^{* *} 0.05 ;{ }^{* * *} 0.10$. Refer to text for variable descriptions. 
Table 3: Trade

\begin{tabular}{|c|c|c|c|c|c|}
\hline Reference & Key independent variable & Dependent variable & Main finding & Setting & Estimation \\
\hline $\begin{array}{l}\text { Autor et al. } \\
\text { (2019) }\end{array}$ & $\begin{array}{l}\text { Chinese import } \\
\text { penetration (shift-share } \\
\text { instrument) }\end{array}$ & $\begin{array}{l}\text { Consumption of polarized } \\
\text { media; political leaning of } \\
\text { campaign contributors; } \\
\text { conservative GOP gains in } \\
\text { Congress }\end{array}$ & $\begin{array}{l}\text { Import shocks from China contribute to: a shift to the } \\
\text { right in media-viewing habits and political beliefs, more } \\
\text { competitive congressional elections, greater polarization } \\
\text { in ideological orientation of campaign contributors, net } \\
\text { gains in the number of conservative GOP representatives, } \\
\text { at the cost of moderate Democrats }\end{array}$ & $\begin{array}{l}\text { U.S., CZs mapped } \\
\text { onto CDs, 1990-2010 }\end{array}$ & OLS, DiD, IV \\
\hline $\begin{array}{l}\text { Ballard-Rosa et } \\
\text { al. (2018) }\end{array}$ & $\begin{array}{l}\text { Chinese import } \\
\text { penetration (based on } \\
A D H \text { instrument) }\end{array}$ & $\begin{array}{l}\text { Authoritarian values (as } \\
\text { measured by a nationally } \\
\text { representative survey) }\end{array}$ & $\begin{array}{l}\text { Individuals in regions where labor markets were more } \\
\text { exposed to increased import from China, and where the } \\
\text { local population is more diverse, express more } \\
\text { authoritarian values }\end{array}$ & U.S., CZs, 2017 & OLS, IV \\
\hline $\begin{array}{l}\text { Barone and } \\
\text { Kreuter (2019) }\end{array}$ & $\begin{array}{l}\text { Chinese import } \\
\text { penetration (based on } \\
\text { ADH instrument) }\end{array}$ & $\begin{array}{l}\text { Vote shares for populist } \\
\text { parties in national elections } \\
\text { for lower house of } \\
\text { parliament }\end{array}$ & $\begin{array}{l}\text { Trade globalization (import competition with China in } \\
\text { particular) increases support for populist parties. Also } \\
\text { increases protest vote by increasing invalid ballot papers } \\
\text { and decreasing turnout }\end{array}$ & $\begin{array}{l}\text { Italy, Municipality, } \\
\text { 1992-2013 }\end{array}$ & OLS, IV \\
\hline $\begin{array}{l}\text { Cerrato et al. } \\
(2018)\end{array}$ & $\begin{array}{l}\text { Chinese import } \\
\text { penetration based on ADH } \\
\text { instrument. Candidates' } \\
\text { mentions of free } \\
\text { trade/immigration: } \\
\text { presidential candidates' } \\
\text { speech data from } \\
\text { American Presidency } \\
\text { Project }\end{array}$ & $\begin{array}{l}\text { Individual appreciation for } \\
\text { Republican presidential } \\
\text { candidates (ANES "feeling } \\
\text { thermometer" data) }\end{array}$ & $\begin{array}{l}\text { 1) Republican candidates consistently assumed harsher } \\
\text { stances on immigration/minority inclusion, moved from } \\
\text { support of free trade to protectionism. 2) Local Chinese } \\
\text { import competition drives negative attitudes toward } \\
\text { immigrants and ethnic/racial minorities. 3) Local import } \\
\text { exposure does not significantly affect attitudes toward } \\
\text { trade integration. 4) Pro-conservative effect mediated by } \\
\text { individual attitudes toward ethnic minorities/religious } \\
\text { groups. }\end{array}$ & $\begin{array}{l}\text { U.S., CD, individual, } \\
2008-2016\end{array}$ & $\begin{array}{l}\text { Text analysis, } \\
\text { IV, IV with } \\
\text { mediator (per } \\
\text { Dippel et al. } \\
\text { 2018) }\end{array}$ \\
\hline $\begin{array}{l}\text { Che et al. } \\
(2017)\end{array}$ & $\begin{array}{l}\text { Exposure to NTR status of } \\
\text { China (employment-share- } \\
\text { weighted industry gap in } \\
\text { tariff induced by NTR) }\end{array}$ & $\begin{array}{l}\text { US House elections, } \\
\text { protectionist voting by } \\
\text { Representatives }\end{array}$ & $\begin{array}{l}\text { Studies the granting of Permanent Normal Trade } \\
\text { Relations to China. U.S. counties subject to greater } \\
\text { competition from China via PNTR exhibit relative } \\
\text { increases in turnout, the share of votes cast for } \\
\text { Democrats and the probability that the county is } \\
\text { represented by a Democrat }\end{array}$ & $\begin{array}{l}\text { U.S., County, 1992- } \\
2010\end{array}$ & $\begin{array}{l}\text { DiD, RD (close } \\
\text { elections), IV }\end{array}$ \\
\hline
\end{tabular}


Table 3: Trade

\begin{tabular}{|c|c|c|c|c|c|}
\hline Reference & Key independent variable & Dependent variable & Main finding & Setting & Estimation \\
\hline $\begin{array}{l}\text { Choi et al. } \\
(2020)\end{array}$ & $\begin{array}{l}\text { NAFTA vulnerability, based } \\
\text { on a Bartik-like variable } \\
\text { that relies on } 1990 \text { tariff } \\
\text { protection and industry } \\
\text { mix }\end{array}$ & $\begin{array}{l}\text { Switch from Democratic to } \\
\text { Republican voting }\end{array}$ & $\begin{array}{l}\text { Exposed counties shift sharply toward the Republican } \\
\text { party in House elections following the } 1993 \text { passage of } \\
\text { NAFTA. Also see employment decline but no population } \\
\text { decline, limited wage effects on average }\end{array}$ & $\begin{array}{l}\text { U.S., CZ, county, } \\
\text { 1980-2016 (focus on } \\
\text { pre/post NAFTA } \\
\text { passage in 1993) }\end{array}$ & Event-study OLS \\
\hline $\begin{array}{l}\text { Colantone and } \\
\text { Stanig (2018a) } \\
\text { "Global } \\
\text { Competition } \\
\text { and Brexit" }\end{array}$ & $\begin{array}{l}\text { Chinese import } \\
\text { penetration (based on } \\
\text { ADH instrument; using } \\
\text { industry specialization in } \\
1989 \text { and } 1990-2007 \text { data) }\end{array}$ & $\begin{array}{l}\text { Regional shares of Brexit } \\
\text { leave votes, individual vote } \\
\text { based on British Election } \\
\text { Study }\end{array}$ & Chinese import shocks lead to higher leave vote share & $\begin{array}{l}\text { U.K., NUTS-3 region, } \\
2016 \text { (Brexit } \\
\text { referendum) }\end{array}$ & OLS, IV \\
\hline $\begin{array}{l}\text { Colantone and } \\
\text { Stanig (2018b) } \\
\text { "The Economic } \\
\text { Determinants... } \\
\text { " }\end{array}$ & $\begin{array}{l}\text { Chinese import } \\
\text { penetration (based on } \\
\text { ADH instrument) }\end{array}$ & $\begin{array}{l}\text { Attitudes from ESS and EVS: } \\
\text { political (toward democracy, } \\
\text { liberalism, etc.); personal } \\
\text { (authoritarian parenting, } \\
\text { traditional values, etc.); } \\
\text { immigration }\end{array}$ & $\begin{array}{l}\text { Chinese import shocks lead to lower support for } \\
\text { democracy and liberal values, but has no bearing on } \\
\text { individual private attitudes. Leads to cultural but not } \\
\text { economic concerns about immigration. }\end{array}$ & $\begin{array}{l}15 \text { Western } \\
\text { European countries, } \\
\text { NUTS-2 region, 1988- } \\
2008\end{array}$ & OLS, IV \\
\hline $\begin{array}{l}\text { Colantone and } \\
\text { Stanig (2018c) } \\
\text { "The Trade } \\
\text { Origins..." }\end{array}$ & $\begin{array}{l}\text { Chinese import shock } \\
\text { (based on ADH } \\
\text { instrument) }\end{array}$ & $\begin{array}{l}\text { Ideology scores from } \\
\text { Comparative Manifesto } \\
\text { Project }\end{array}$ & $\begin{array}{l}\text { Chinese import shocks lead to increased support for 1) } \\
\text { nationalist and isolationist parties, 2) increased support } \\
\text { for radical-right parties, an 3) a general rightward shift in } \\
\text { electorate }\end{array}$ & $\begin{array}{l}15 \text { Western } \\
\text { European countries, } \\
\text { NUTS-2 region, 1988- } \\
2007\end{array}$ & OLS, IV \\
\hline $\begin{array}{l}\text { Dippel et al. } \\
\text { (2018) (builds } \\
\text { on their } 2015 \\
\text { WP, which is } \\
\text { focused less on } \\
\text { the metrics } \\
\text { component) }\end{array}$ & $\begin{array}{l}\text { Imports from/exports to } \\
\text { China with ADHM } \\
\text { instrument, labor market } \\
\text { conditions from IAB's HES } \\
\text { database }\end{array}$ & $\begin{array}{l}\text { Party vote shares in federal } \\
\text { elections }\end{array}$ & $\begin{array}{l}\text { Find effect of trade exposure on far-right populist voting, } \\
\text { but not on other-party votes. When considering the } \\
\text { Trade exposure -> Labor market effects -> Populist voting } \\
\text { channel, find that labor market explains } 107-137 \% \text { of } \\
\text { total effects on populist voting due to trade exposure. Do } \\
\text { some additional analysis to relax these bounds if } \\
\text { identification assumptions are relaxed, find that labor } \\
\text { market explains at least } 70 \% \text { of total efect }\end{array}$ & $\begin{array}{l}\text { Germany, County } \\
\text { (Landkreis), 1987- } \\
2009\end{array}$ & $\begin{array}{l}\text { OLS, IV, IV with } \\
\text { mediator }\end{array}$ \\
\hline $\begin{array}{l}\text { Jensen et al. } \\
\text { (2017) }\end{array}$ & $\begin{array}{l}\text { Trade exposure in goods } \\
\text { and services, } \\
\text { distinguishing between } \\
\text { import and export } \\
\text { exposure }\end{array}$ & $\begin{array}{l}\text { Incumbent vote share in U.S. } \\
\text { presidential elections }\end{array}$ & $\begin{array}{l}\text { Incumbents fare worse in counties experiencing a drop in } \\
\text { low-wage manufacturing employment, but fare better } \\
\text { when employment rises in high-wage manufacturing and } \\
\text { service sectors }\end{array}$ & $\begin{array}{l}\text { U.S., County, Labor } \\
\text { Market Area, 1992- } \\
2012\end{array}$ & OLS \\
\hline
\end{tabular}


Table 3: Trade

\begin{tabular}{|c|c|c|c|c|c|}
\hline Reference & Key independent variable & Dependent variable & Main finding & Setting & Estimation \\
\hline $\begin{array}{l}\text { Malgouyres } \\
(2017)\end{array}$ & $\begin{array}{l}\text { Imports exposure based } \\
\text { on sector exposure to low- } \\
\text { wage country imports, } \\
\text { instrumented with China } \\
\text { export exposure of other } \\
\text { similar countries (data: } \\
\text { DADS matched employer- } \\
\text { employee dataset, UN } \\
\text { Comtrade trade flows) }\end{array}$ & $\begin{array}{l}\text { Front National vote share in } \\
\text { national elections }\end{array}$ & $\begin{array}{l}\text { Small but significant effect of import exposure on the } \\
\text { propensity of communities to vote for the FN }\end{array}$ & $\begin{array}{l}\text { France, Small } \\
\text { communities } \\
\text { (cantons), 1995-2012 }\end{array}$ & OLS, IV \\
\hline Margalit (2011) & $\begin{array}{l}\text { Requests for trade } \\
\text { adjustment assistance } \\
\text { from Department of Labor }\end{array}$ & $\begin{array}{l}\text { Incumbent vote share in U.S. } \\
\text { presidential elections (with } \\
\text { focus on change in George } \\
\text { W. Bush vote share in } 2000 \\
\text { and } 2004 \text { elections) }\end{array}$ & $\begin{array}{l}\text { A } 1 \mathrm{pp} \text { increase in the share of county workforce losing a } \\
\text { job due to foreign competition lowers incumbent vote } \\
\text { share by } 0.15 \mathrm{pp} \text {, twice as large as the vote share } \\
\text { dropdue to job losses caused by other factors }\end{array}$ & $\begin{array}{l}\text { U.S., County, 1996- } \\
2004\end{array}$ & OLS \\
\hline $\begin{array}{l}\text { Rommel and } \\
\text { Walter (2017) }\end{array}$ & $\begin{array}{l}\text { Exposure to occupation, } \\
\text { respondent education } \\
\text { (from ESS) }\end{array}$ & $\begin{array}{l}\text { Economic policy preferences } \\
\text { and support for various } \\
\text { families of political parties } \\
\text { (from Comparative Manifesto } \\
\text { Project) }\end{array}$ & $\begin{array}{l}\text { Offshorability associated with support for leftist and } \\
\text { center-right parties, not associated with support for } \\
\text { populist right parties }\end{array}$ & $\begin{array}{l}18 \text { Western } \\
\text { European countries, } \\
\text { Individual, 2002- } \\
2010\end{array}$ & $\begin{array}{l}\text { OLS, probit } \\
\text { random effects }\end{array}$ \\
\hline $\begin{array}{l}\text { Steiner and } \\
\text { Harms (2020) }\end{array}$ & $\begin{array}{l}\text { China shift-share import } \\
\text { penetration variable }\end{array}$ & $\begin{array}{l}\text { Within-individual changes in } \\
\text { attitudes on nationalism and } \\
\text { economic policy }\end{array}$ & $\begin{array}{l}\text { Individuals in regions with greater exposure to higher } \\
\text { imports from China express more nationalistic sentiments } \\
\text { and become more critical of EU and international } \\
\text { cooperation. There is no evidence that trade shocks } \\
\text { produce economic policy attitudes to shift to the left. }\end{array}$ & $\begin{array}{l}\text { British Household } \\
\text { Panel Study, } \\
\text { individual, 1999- } \\
2008\end{array}$ & $\begin{array}{l}\text { OLS, with } \\
\text { lagged } \\
\text { individual } \\
\text { preferences }\end{array}$ \\
\hline
\end{tabular}


Table 4: Immigration

\begin{tabular}{|c|c|c|c|c|c|}
\hline Reference & Key independent variable & Dependent variable & Main finding & Setting & Estimation \\
\hline $\begin{array}{l}\text { Barone et al. } \\
\text { (2016) }\end{array}$ & $\begin{array}{l}\text { Immigrant share, using } \\
\text { shift-share IV }\end{array}$ & $\begin{array}{l}\text { Center-right vote share } \\
\text { (which includes extreme and } \\
\text { moderate right) }\end{array}$ & $\begin{array}{l}\text { More voting for center-right coalition in municipalities } \\
\text { with larger inflows of immigrants. Smaller absolute (but } \\
\text { greater relative) effect on extreme-right voting than on } \\
\text { moderate right voting. }\end{array}$ & $\begin{array}{l}\text { Italy, Municipality, } \\
2001-2008\end{array}$ & OLS, IV \\
\hline $\begin{array}{l}\text { Becker and } \\
\text { Fetzer (2017) }\end{array}$ & $\begin{array}{l}\text { Migration from accession } \\
\text { countries (relative to EU } \\
\text { migration in the past, and } \\
\text { to total population) }\end{array}$ & $\begin{array}{l}\text { Vote shares for UKIP party in } \\
\text { European Parliamentary } \\
\text { elections. Also use British } \\
\text { Election Study data on } \\
\text { individual preferences }\end{array}$ & $\begin{array}{l}\text { Places that received large numbers of migrants from } \\
\text { Eastern Europe saw small, but statistically significant } \\
\text { increases in the vote shares for the UKIP. EU accession } \\
\text { decreased wages at lower end of income distribution }\end{array}$ & $\begin{array}{l}\text { U.K., Local authority } \\
\text { district, individual, } \\
\text { 1999-2014 (with } \\
\text { focus on } 2004 \\
\text { migration shock) }\end{array}$ & $\begin{array}{l}\text { Best subset } \\
\text { selection, DiD } \\
\text { using } \\
\text { propensity } \\
\text { score matching }\end{array}$ \\
\hline $\begin{array}{l}\text { Becker et al. } \\
(2016)\end{array}$ & Growth rate of migrants & $\begin{array}{l}\text { Brexit leave vote in } 380 \text { local } \\
\text { authorities }\end{array}$ & $\begin{array}{l}\text { Vote Leave share strongly associated with growth rate of } \\
\text { migrants from EU accession countries. Also strongly } \\
\text { associated with old age, low education, high } \\
\text { manufacturing employment share, high unemployment. }\end{array}$ & $\begin{array}{l}\text { U.K., Local authority } \\
\text { areas, wards, } 2016 \\
\text { (Brexit referendum) }\end{array}$ & $\begin{array}{l}\text { OLS, penalized } \\
\text { OLS }\end{array}$ \\
\hline $\begin{array}{l}\text { Brunner and } \\
\text { Kuhn (2018) }\end{array}$ & $\begin{array}{l}\text { Immigrant share, } \\
\text { instrumented with } \\
\text { immigrant share in } \\
\text { (broader) local labor } \\
\text { market. Also incorporate } \\
\text { cultural distance measure }\end{array}$ & $\begin{array}{l}\text { Shares of anti-immigrant } \\
\text { votes (based on votes on } \\
\text { amendments related to } \\
\text { migration policy, taking } \\
\text { advantage of Swiss direct } \\
\text { democracy); vote share of } \\
\text { Swiss People's Party }\end{array}$ & $\begin{array}{l}1 \mathrm{pp} \text { increase in the local share of culturally different } \\
\text { immigrants results in a } 1.25 \mathrm{pp} \text { increase in anti- } \\
\text { immigration votes in an average national vote about } \\
\text { immigration. Also see increase in vote shares for right- } \\
\text { wing Swiss People's Party }\end{array}$ & $\begin{array}{l}\text { Switzerland, } \\
\text { Community, 1970- } \\
2010\end{array}$ & OLS, IV \\
\hline $\begin{array}{l}\text { Caselli et al. } \\
(2020)\end{array}$ & $\begin{array}{l}\text { Change in immigrant } \\
\text { stock, shift-share } \\
\text { instruments for Chinese } \\
\text { imports and robotization }\end{array}$ & Vote share of far-right parties & $\begin{array}{l}\text { Over 2001-2008, greater immigration, larger trade shock, } \\
\text { and robotization are all associated with greater support } \\
\text { for far-right parties. Over 2008-2013, greater immigration } \\
\text { is associated with less support for far-right parties but } \\
\text { with more support for the new Five Star movement. No } \\
\text { effect of Chinese imports is found in the latter period. }\end{array}$ & $\begin{array}{l}\text { Italy, local labor } \\
\text { markets, 2001, 2008, } \\
2013\end{array}$ & IV \\
\hline $\begin{array}{l}\text { Dinas et al. } \\
\text { (2019) }\end{array}$ & $\begin{array}{l}\text { Refugee influxes in some } \\
\text { Aegean islands (natural } \\
\text { experiment -- also does IV } \\
\text { using distance from } \\
\text { Turkish coast) }\end{array}$ & $\begin{array}{l}\text { Vote shares for Golden } \\
\text { Dawn, an extreme right-wing } \\
\text { Greek party }\end{array}$ & $\begin{array}{l}\text { Increase in vote share for Golden Dawn in islands } \\
\text { impacted by refugee crisis }\end{array}$ & $\begin{array}{l}\text { Greece, } \\
\text { Island/municipality, } \\
2015 \text { (compares Jan } \\
\text { and Sep elections) }\end{array}$ & OLS, DiD, IV \\
\hline
\end{tabular}




\section{Table 4: Immigration}

\begin{tabular}{|c|c|c|c|c|c|}
\hline Reference & Key independent variable & Dependent variable & Main finding & Setting & Estimation \\
\hline $\begin{array}{l}\text { Dustmann et al. } \\
\text { (2016) }\end{array}$ & $\begin{array}{l}\text { Change in refugee } \\
\text { allocation (under a quasi- } \\
\text { random allocation policy) }\end{array}$ & $\begin{array}{l}\text { Change in vote share for anti- } \\
\text { immigrant/far-right parties }\end{array}$ & $\begin{array}{l}\text { Increase in refugee share significantly increases vote } \\
\text { share for anti-immigrant and both far-right and center- } \\
\text { right parties }\end{array}$ & $\begin{array}{l}\text { Denmark, } \\
\text { Municipality, 1989- } \\
1998\end{array}$ & $\begin{array}{l}\text { OLS (with } \\
\text { natural } \\
\text { experiment } \\
\text { geneating quasi- } \\
\text { random } \\
\text { variation) }\end{array}$ \\
\hline $\begin{array}{l}\text { Edo et al. } \\
(2019)\end{array}$ & $\begin{array}{l}\text { Immigrant share, using } \\
\text { shift-share IV }\end{array}$ & $\begin{array}{l}\text { Vote shares for far-right and } \\
\text { far-left parties }\end{array}$ & $\begin{array}{l}\text { OLS and IV estimates suggest that immigration increases } \\
\text { support for far-right candidates and tends to have a weak } \\
\text { negative effect on the support for far-left candidates at } \\
\text { the departmental and regional levels. Effect on far-right } \\
\text { driven by low-educated immigrants from non-Western } \\
\text { countries }\end{array}$ & $\begin{array}{l}\text { France, Department, } \\
\text { municipality, canton, } \\
\text { 1988-2017 }\end{array}$ & $\begin{array}{l}\text { Multinomial } \\
\text { logit, OLS, IV }\end{array}$ \\
\hline $\begin{array}{l}\text { Eichengreen et } \\
\text { al. (2017) }\end{array}$ & $\begin{array}{l}\text { Foreign pop share, } \\
\text { manufacturing/farm } \\
\text { output }\end{array}$ & $\begin{array}{l}\text { Vote share for Bryan } \\
\text { (populist in } 1896 \text { election) }\end{array}$ & $\begin{array}{l}\text { Bryan vote share lower in manufacturing counties, higher } \\
\text { in those with larger Chinese share, also associated with } \\
\text { crop prices and mortgage interest rates }\end{array}$ & $\begin{array}{l}\text { U.S., County, } 1896 \\
\text { (McKinley-Bryan } \\
\text { election) }\end{array}$ & OLS \\
\hline $\begin{array}{l}\text { Gerdes and } \\
\text { Wadensjö } \\
(2010)\end{array}$ & $\begin{array}{l}\text { Share of population of non- } \\
\text { Western origin }\end{array}$ & $\begin{array}{l}\text { Vote shares for various } \\
\text { parties, with a focus on far- } \\
\text { left and far-right parties }\end{array}$ & $\begin{array}{l}\text { Anti-immigration parties win votes as a result of increase } \\
\text { in non-western share, but so does a pro-immigation party }\end{array}$ & $\begin{array}{l}\text { Denmark, } \\
\text { Municipality, 1989- } \\
2001\end{array}$ & $\begin{array}{l}\text { OLS (fixed- } \\
\text { effect } \\
\text { specification), } \\
\text { IV }\end{array}$ \\
\hline $\begin{array}{l}\text { Halla et al. } \\
\text { (2017) }\end{array}$ & $\begin{array}{l}\text { Immigrant share (and } \\
\text { changes in immigrant } \\
\text { share), uses Bartik style IV }\end{array}$ & $\begin{array}{l}\text { Vote shares for FPÖ } \\
\text { (Freedom Party of Austria, a } \\
\text { far-right party) }\end{array}$ & $\begin{array}{l}\text { Inflow of immigrants into community has significant } \\
\text { impact on FPÖ vote share }\end{array}$ & $\begin{array}{l}\text { Australia, } \\
\text { Community, 1971- } \\
2013\end{array}$ & OLS, IV \\
\hline Harmon (2018) & $\begin{array}{l}\text { Share of population of non- } \\
\text { Western origin, } \\
\text { instrumented with } \\
\text { measure of availability of } \\
\text { rental housing in } 1970\end{array}$ & $\begin{array}{l}\text { Vote shares in municipal } \\
\text { elections of } 1981 \text { and } 2001 \\
\text { and in national elections, of } \\
\text { far-left and far-right parties }\end{array}$ & $\begin{array}{l}\text { Increasing ethnic diversity has a negative effect on the } \\
\text { electoral success of traditional left-wing parties and a } \\
\text { positive effect on the electoral success of anti-immigrant } \\
\text { nationalist parties }\end{array}$ & $\begin{array}{l}\text { Denmark, } \\
\text { Municipality, 1981- } \\
2001\end{array}$ & OLS, IV \\
\hline Hill et al. (2019) & $\begin{array}{l}\text { Shares of Hispanic and non- } \\
\text { citizen foreign-born } \\
\text { population }\end{array}$ & $\begin{array}{l}\text { Change in Republican vote } \\
\text { share in Presidential } \\
\text { elections }\end{array}$ & $\begin{array}{l}\text { There is a negative relationship between increase in } \\
\text { Hispanic shares and increase in Republican (Trump) vote } \\
\text { share }\end{array}$ & $\begin{array}{l}\text { U.S., precinct-level } \\
\text { observations in } 7 \\
\text { states, } 2012-2016\end{array}$ & OLS \\
\hline
\end{tabular}


Table 4: Immigration

\begin{tabular}{|c|c|c|c|c|c|}
\hline Reference & Key independent variable & Dependent variable & Main finding & Setting & Estimation \\
\hline $\begin{array}{l}\text { Mayda et al. } \\
\text { (2019) }\end{array}$ & $\begin{array}{l}\text { Low and high skilled } \\
\text { immigrant share, with shift- } \\
\text { share style instrument }\end{array}$ & $\begin{array}{l}\text { Vote shares for Republicans } \\
\text { in House, Senate, and } \\
\text { presidential elections; Pew } \\
\text { survey data }\end{array}$ & $\begin{array}{l}\text { Increase in high-skilled immigrants decreases the share of } \\
\text { Republican votes, while an inflow of low-skilled } \\
\text { immigrants increases it. Mostly due to effect on existing } \\
\text { citizens' votes, independent of country of origin }\end{array}$ & $\begin{array}{l}\text { U.S., County, } \\
\text { individual, 1990- } \\
2010\end{array}$ & OLS, IV \\
\hline $\begin{array}{l}\text { Mendez and } \\
\text { Cutillas (2014) }\end{array}$ & $\begin{array}{l}\text { (Change in) foreign-born } \\
\text { population share, with } \\
\text { shift-share instrument }\end{array}$ & $\begin{array}{l}\text { Change in vote for major } \\
\text { leftist (PSOE) over major } \\
\text { conservative (PP) party in } \\
\text { presidential elections, vote } \\
\text { share for anti-immigrant } \\
\text { formations (parties) }\end{array}$ & $\begin{array}{l}\text { Latin-American immigration increased natives' } \\
\text { participation rate and their support for the major leftist } \\
\text { party (PSOE) over the major conservativeparty (PP). } \\
\text { African immigration increased natives' support for anti- } \\
\text { immigration formations relative to the PP, leaving } \\
\text { unaffected the participation rate }\end{array}$ & $\begin{array}{l}\text { Spain, Province, } \\
1996-2011\end{array}$ & OLS, IV \\
\hline $\begin{array}{l}\text { Moriconi et al. } \\
\text { (2018) }\end{array}$ & $\begin{array}{l}\text { High- and low-skilled } \\
\text { immigrant share, using } \\
\text { shift-share IV }\end{array}$ & $\begin{array}{l}\text { Party that individual voted } \\
\text { for/supports, scored based } \\
\text { on its nationalist bent (per } \\
\text { the Manifesto Project). Uses } \\
\text { data from ESS }\end{array}$ & $\begin{array}{l}\text { Strong negative association between highly-educated } \\
\text { immigrant share \& nationalist intensity; strong positive } \\
\text { association between less-educated immigrant share \& } \\
\text { nationalist intensity; changes in prefs in response to high- } \\
\text { and low-skilled immigrant share is stronger for less- } \\
\text { educated and older voters. Shift mostly driven by change } \\
\text { in vote preferences, not turnout }\end{array}$ & $\begin{array}{l}12 \text { European } \\
\text { countries, Individual, } \\
2007-2016\end{array}$ & OLS, IV \\
\hline $\begin{array}{l}\text { Otto and } \\
\text { Steinhardt } \\
(2014)\end{array}$ & $\begin{array}{l}\text { Foreign-born population } \\
\text { share, with shift-share } \\
\text { instrument }\end{array}$ & $\begin{array}{l}\text { Vote shares for far-right and } \\
\text { Green parties in regional and } \\
\text { national elections }\end{array}$ & $\begin{array}{l}\text { Positive and substantial impact of growing shares of } \\
\text { foreigners on the political success of extreme right-wing } \\
\text { parties, negative association with vote share for Green } \\
\text { party }\end{array}$ & $\begin{array}{l}\text { Germany (Hamburg), } \\
\text { City district, 1987- } \\
2000\end{array}$ & $\begin{array}{l}\text { OLS (fixed- } \\
\text { effect } \\
\text { specification), } \\
\text { IV }\end{array}$ \\
\hline $\begin{array}{l}\text { Roupakias and } \\
\text { Chletsos (2020) }\end{array}$ & $\begin{array}{l}\text { Share of immigrants in } \\
\text { local population, with shift- } \\
\text { share instrument }\end{array}$ & $\begin{array}{l}\text { Vote share of three far right } \\
\text { parties in national elections }\end{array}$ & $\begin{array}{l}\text { An increase in the immigrant share, especially from non- } \\
\text { OECD countries, increases support for far right parties, } \\
\text { while decreasing support for far left party (Syriza) }\end{array}$ & $\begin{array}{l}\text { Greece, } 51 \text { regions, } \\
2004-2012\end{array}$ & $\begin{array}{l}\text { IV with fixed } \\
\text { effects for } \\
\text { regions; WLS; } \\
\text { OLS }\end{array}$ \\
\hline Tabellini (2019) & $\begin{array}{l}\text { European immigration to } \\
\text { U.S. cities (exogenous } \\
\text { variation ue to policy } \\
\text { changes; also shift-share } \\
\text { IV) }\end{array}$ & $\begin{array}{l}\text { Public spending, legislator } \\
\text { ideology }\end{array}$ & $\begin{array}{l}\text { Immigration triggered hostile political reactions, such as } \\
\text { the election of more conservative legislators, higher } \\
\text { support for anti-immigration legislation, and lower } \\
\text { redistribution. }\end{array}$ & $\begin{array}{l}\text { U.S., Cities, 1910- } \\
1930\end{array}$ & OLS, IV \\
\hline
\end{tabular}


Table 4: Immigration

\begin{tabular}{|c|c|c|c|c|c|}
\hline Reference & Key independent variable & Dependent variable & Main finding & Setting & Estimation \\
\hline $\begin{array}{l}\text { Vertier and } \\
\text { Viskanic (2019) }\end{array}$ & $\begin{array}{l}\text { Presence of temporary } \\
\text { migrant centers (CAOs), } \\
\text { instrumented with } \\
\text { presence of holiday village } \\
\text { in same municipality }\end{array}$ & $\begin{array}{l}\text { Change in vote share for } \\
\text { Front National between } 2012 \\
\text { and } 2017\end{array}$ & $\begin{array}{l}\text { In the presence of a CAO, the percentage growth rate of } \\
\text { vote shares for the FN between } 2012 \text { and } 2017 \text { is reduced } \\
\text { by about } 12.3 p p \text {. Effects dissipate spatially and are most } \\
\text { pronounced for cities that received small number of } \\
\text { migrants, suggestive of contact hypothesis }\end{array}$ & $\begin{array}{l}\text { France, Municipality, } \\
\text { 2012-2017 }\end{array}$ & OLS, IV \\
\hline
\end{tabular}


Table 5: Financial globalization

\begin{tabular}{|c|c|c|c|c|c|}
\hline Reference & Key independent variable & Dependent variable & Main finding & Setting & Estimation \\
\hline $\begin{array}{l}\text { Ahlquist et al. } \\
\text { (2018) }\end{array}$ & $\begin{array}{l}\text { Repayment of mortgages } \\
\text { denominated in Swiss } \\
\text { francs. (Take advantage of } \\
\text { surprise revaluation of } \\
\text { Swiss franc in 2015) }\end{array}$ & $\begin{array}{l}\text { Vote shares for PiS (populist- } \\
\text { right party) demand for } \\
\text { government bailouts. } \\
\text { Authors' survey data from } \\
\text { 2015, prior to election }\end{array}$ & $\begin{array}{l}\text { Those exposed to shock more likely to demand } \\
\text { government support. Among former government voters, } \\
\text { Swiss franc borrowers were more likely to desert the } \\
\text { government and vote for the largest opposition party, the } \\
\text { PiS. This brought the PiS a parliamentary majority }\end{array}$ & $\begin{array}{l}\text { Poland, Individual, } \\
2015\end{array}$ & $\begin{array}{l}\text { Logistic } \\
\text { regression }\end{array}$ \\
\hline $\begin{array}{l}\text { Bergh and } \\
\text { Gustafsson } \\
\text { (2019) }\end{array}$ & $\begin{array}{l}\text { KOF globalization index } \\
\text { (combines trade and } \\
\text { financial globalization) }\end{array}$ & $\begin{array}{l}\text { Vote shares of European } \\
\text { populist parties }\end{array}$ & $\begin{array}{l}\text { Increase in vote share for populist parties positively } \\
\text { associated with globalization index }\end{array}$ & $\begin{array}{l}33 \text { European } \\
\text { countries, Country, } \\
1980-2016\end{array}$ & OLS \\
\hline $\begin{array}{l}\text { Doerr et al. } \\
\text { (2019) }\end{array}$ & $\begin{array}{l}\text { Exposure to bank failures } \\
\text { (particularly those of } \\
\text { Danat and Dresdner), } \\
\text { using data on firm-bank } \\
\text { relationshps for } 5610 \text { firms } \\
\text { during the Great } \\
\text { Depression. Digitized for } \\
\text { the first time by authors }\end{array}$ & Nazi vote shares & $\begin{array}{l}\text { Greater exposure to bank failure in } 1930 \text {-> greater Nazi } \\
\text { gains. Unemployment did not impact Nazi support, but } \\
\text { income decline driven by exposure to Jewish-led bank led } \\
\text { to sizable increase in Nazi support (relative to other } \\
\text { failing non-Jewish bank). Places with history of anti- } \\
\text { Semitism showed greater effect. In places without this } \\
\text { history, income change accounted for all the political } \\
\text { change }\end{array}$ & $\begin{array}{l}\text { Germany, Bank-firm } \\
\text { pair (each firm } \\
\text { typically was closely } \\
\text { connected to one } \\
\text { bank), city, } 1931 \\
\text { (banking crisis-- } \\
\text { studies Nazi Party } \\
\text { support between } \\
1930 \text { and } 1932 / 33 \text { ) }\end{array}$ & OLS \\
\hline $\begin{array}{l}\text { Funke et al. } \\
(2016)\end{array}$ & Financial crises & $\begin{array}{l}\text { Vote shares of far-left and far- } \\
\text { right parties in parliamentary } \\
\text { elections; street protests }\end{array}$ & $\begin{array}{l}\text { Post-crisis: vote swings to far-right parties; increased } \\
\text { fragmentation and street protests. Far-right parties } \\
\text { increase vote share by } 30 \% \text { after financial crisis, but not } \\
\text { after normal recessions or non-financial macro shocks. }\end{array}$ & $\begin{array}{l}20 \text { developed } \\
\text { countries, Country, } \\
1870-2014\end{array}$ & $\begin{array}{l}\text { OLS, local } \\
\text { projection }\end{array}$ \\
\hline $\begin{array}{l}\text { Gyöngyösi and } \\
\text { Verner (2020) }\end{array}$ & $\begin{array}{l}\text { Foreign currency } \\
\text { borrowing/debt exposure }\end{array}$ & $\begin{array}{l}\text { Far-right vote shares in } \\
\text { Parliamentary election }\end{array}$ & $\begin{array}{l}\text { Vote share of populist far-right increased significantly } \\
\text { more in zip codes with greater exposure to household } \\
\text { foreign currency debt }\end{array}$ & $\begin{array}{l}\text { Hungary, Zip code, } \\
\text { 1998-2018 (focus on } \\
\text { 2010) }\end{array}$ & OLS \\
\hline $\begin{array}{l}\text { Mian et al. } \\
\text { (2014) }\end{array}$ & $\begin{array}{l}\text { Banking, currency, } \\
\text { inflation, debt crises (using } \\
\text { Reinhart and Rogoff } \\
\text { comprehensive dataset on } \\
\text { financial crises) }\end{array}$ & $\begin{array}{l}\text { Size of governing coalition; } \\
\text { political } \\
\text { fragmentation/fractionalizati } \\
\text { on; vote shares of } \\
\text { government parties; political } \\
\text { poliarization/leaning (WVS, } \\
\text { ANES, DPI data)j; IMF } \\
\text { structural reforms }\end{array}$ & $\begin{array}{l}\text { Following a financial crisis, voters become more extreme, } \\
\text { ruling coalitions become weaker, fractionalization } \\
\text { increases. Financial crises put pressure on debtors, and } \\
\text { the debt overhang/creditor-debtor conflict that occurs } \\
\text { afterward tends to deepen the downturn }\end{array}$ & $\begin{array}{l}70 \text { countries (from } \\
\text { RR dataset), Country, } \\
1975-2010\end{array}$ & \\
\hline
\end{tabular}


Table 5: Financial globalization

\begin{tabular}{|c|c|c|c|c|c|}
\hline Reference & Key independent variable & Dependent variable & Main finding & Setting & Estimation \\
\hline $\begin{array}{l}\text { Swank and Betz } \\
\text { (2003) }\end{array}$ & $\begin{array}{l}\text { Trade openness, capital } \\
\text { mobility, foreign asylum } \\
\text { seekers, social welfare } \\
\text { protection at national level }\end{array}$ & $\begin{array}{l}\text { Vote shares for radical right- } \\
\text { wing populist parties in } \\
\text { national parliamentary } \\
\text { elections }\end{array}$ & $\begin{array}{l}\text { Trade openness and transnational flows of capital have } \\
\text { contributed to success of radical right-wing parties in } \\
\text { Western Europe. However, effect is attenuated in states } \\
\text { with strong welfare }\end{array}$ & $\begin{array}{l}16 \text { Western } \\
\text { European countries, } \\
\text { Election, 1981-1998 }\end{array}$ & Tobit MLE \\
\hline
\end{tabular}


Table 6: Economic insecurity

\begin{tabular}{|c|c|c|c|c|c|}
\hline Reference & Key independent variable & Dependent variable & Main finding & Setting & Estimation \\
\hline $\begin{array}{l}\text { Algan et al. } \\
(2017)\end{array}$ & $\begin{array}{l}\text { Unemployment } \\
\text { (instrumented with } \\
\text { construction share) }\end{array}$ & $\begin{array}{l}\text { Vote shares of populist } \\
\text { parties; Brexit vote; } \\
\text { trust/attitudes (toward } \\
\text { immigrants, police, etc.) from } \\
\text { ESS }\end{array}$ & $\begin{array}{l}\text { Increase in unemployment during crisis associated } \\
\text { w/increased voting for populist parties, decreased trust in } \\
\text { political institutions }\end{array}$ & $\begin{array}{l}26 \text { EU countries, } \\
\text { NUTS-2 region, } 2000- \\
2017\end{array}$ & OLS, DiD, IV \\
\hline $\begin{array}{l}\text { Anelli et al. } \\
\text { (2019) }\end{array}$ & $\begin{array}{l}\text { Exposure to automation } \\
\text { (regional based on } \\
\text { industry mix; individual } \\
\text { based on occupation; } \\
\text { instrumented with other- } \\
\text { country robot use) }\end{array}$ & $\begin{array}{l}\text { Ideological leaning of } \\
\text { electoral districts/indiv. } \\
\text { votes, based on nationalism } \\
\text { scores from Manifesto } \\
\text { Project }\end{array}$ & $\begin{array}{l}\text { Higher exposure to automation increases support for } \\
\text { nationalist and radical-right parties, both at the regional } \\
\text { and at the individual level }\end{array}$ & $\begin{array}{l}14 \text { Western } \\
\text { European countries, } \\
\text { NUTS-2 region, 1993- } \\
2016\end{array}$ & OLS, IV \\
\hline $\begin{array}{l}\text { Bossert et al. } \\
\text { (2019) }\end{array}$ & $\begin{array}{l}\text { Economic insecurity (a } \\
\text { measure based on changes } \\
\text { in income) }\end{array}$ & Support for political parties & $\begin{array}{l}\text { Economic insecurity predicts support for parties of the } \\
\text { right, greater support for Donald Trump before the } 2016 \\
\text { US Presidential election, and theUK leaving the European } \\
\text { Union in the } 2016 \text { Brexit referendum. }\end{array}$ & $\begin{array}{l}\text { UK, U.S., and } \\
\text { Germany, panel of } \\
\text { individuals }\end{array}$ & $\begin{array}{l}\text { logistic } \\
\text { regressions }\end{array}$ \\
\hline Chen (2018) & Unemployment & $\begin{array}{l}\text { Voting for Sanders/Trump; } \\
\text { GSS attitudes/trust measures }\end{array}$ & $\begin{array}{l}\text { Unemployment during Great Recession associated with } \\
\text { increased left-wing populism; higher immigrant inflows } \\
\text { associated with increased right-wing populism }\end{array}$ & $\begin{array}{l}\text { U.S., } \\
\text { Individual/"region" } \\
\text { (9 total in the U.S.), } \\
2006-2016\end{array}$ & $\begin{array}{l}\text { DiD, logistic } \\
\text { fixed effects }\end{array}$ \\
\hline $\begin{array}{l}\text { Dal Bó et al. } \\
\text { (2019) }\end{array}$ & $\begin{array}{l}\text { Economic "winners" and } \\
\text { "losers" due to 2006-2011 } \\
\text { policy reforms. Individuals } \\
\text { classified based on register } \\
\text { data and based on risk of } \\
\text { automation replacement }\end{array}$ & $\begin{array}{l}\text { Vote shares of Sweden } \\
\text { Democrats }\end{array}$ & $\begin{array}{l}\text { Local increase in "insider-outsider gap" and share of } \\
\text { "vulnerable insiders" associated with larger gains for } \\
\text { Sweden Democrats }\end{array}$ & $\begin{array}{l}\text { Sweden, Individual, } \\
\text { precinct, } \\
\text { municipality, 1979- } \\
2012\end{array}$ & OLS \\
\hline $\begin{array}{l}\text { De Bromhead } \\
\text { et al. (2013) }\end{array}$ & $\begin{array}{l}\text { Pre/post } 1929 \text { (market } \\
\text { crash), GDP growth }\end{array}$ & $\begin{array}{l}\text { Vote shares of fascist anti- } \\
\text { system parties and of } \\
\text { communist parties }\end{array}$ & $\begin{array}{l}\text { GDP growth was negatively related to the vote for } \\
\text { extreme right-wing parties. "impact was } \\
\text { greatest in countries with relatively short histories of } \\
\text { democracy, with electoral } \\
\text { systems that created low hurdles to parliamentary } \\
\text { representation, and which had } \\
\text { been on the losing side in World War I." }\end{array}$ & $\begin{array}{l}28 \text { countries, } \\
\text { Election, 1919-1939 }\end{array}$ & $\begin{array}{l}\text { Semi- } \\
\text { parametric } \\
\text { fixed-effects } \\
\text { Tobit }\end{array}$ \\
\hline
\end{tabular}


Table 6: Economic insecurity

\begin{tabular}{|c|c|c|c|c|c|}
\hline Reference & Key independent variable & Dependent variable & Main finding & Setting & Estimation \\
\hline Fetzer (2019) & $\begin{array}{l}\text { Exposure to welfare cuts } \\
\text { at district level (dawing on } \\
\text { Beatty and Fothergill } 2013 \\
\text { data), individual exposure } \\
\text { to benefits from USOC } \\
\text { survey }\end{array}$ & $\begin{array}{l}\text { Vote shares for UKIP from } \\
\text { Westminster, European, and } \\
\text { local council elections; newly } \\
\text { constructed individual panel } \\
\text { dataset }\end{array}$ & $\begin{array}{l}\text { Significant association between exposure to UK } \\
\text { government austerity-induced welfare cuts and } \\
\text { subsequent support for UK Independence Party }\end{array}$ & $\begin{array}{l}\text { U.K. Local authority } \\
\text { district, } \\
\text { constituency, } \\
\text { individual, } 2000 \text { - } \\
2016 \text { (focus on } 2010 \\
\text { reforms) }\end{array}$ & $\begin{array}{l}\text { OLS, IV (event- } \\
\text { study } \\
\text { specification) }\end{array}$ \\
\hline $\begin{array}{l}\text { Gomez and } \\
\text { Ramiro (2017) }\end{array}$ & $\begin{array}{l}\text { Unemployment rate at the } \\
\text { national level }\end{array}$ & $\begin{array}{l}\text { Dichotomous variable } \\
\text { indicating whether } \\
\text { respondent voted for a } \\
\text { radical left party }\end{array}$ & $\begin{array}{l}\text { Higher unemployment is associated with greater } \\
\text { propensity to vote for radical left parties }\end{array}$ & $\begin{array}{l}56 \text { elections in } 15 \\
\text { European countries, } \\
1996-2016\end{array}$ & $\begin{array}{l}\text { OLS, with } \\
\text { individual level } \\
\text { controls }\end{array}$ \\
\hline $\begin{array}{l}\text { Guiso et al. } \\
\text { (2018) }\end{array}$ & $\begin{array}{l}\text { Economic insecurity, } \\
\text { attitudes, education (ESS } \\
\text { data) }\end{array}$ & $\begin{array}{l}\text { Vote shares of populist } \\
\text { parties (using van Kessel } \\
\text { definition and a 3D } \\
\text { definition); also emphasize } \\
\text { turnout }\end{array}$ & $\begin{array}{l}\text { Economic insecurity is associated with increased voting } \\
\text { for populist parties but decreased turnout }\end{array}$ & $\begin{array}{l}\text { All European } \\
\text { countries, Individual, } \\
2002-2014\end{array}$ & $\begin{array}{l}\text { Two-step } \\
\text { Heckman probit }\end{array}$ \\
\hline $\begin{array}{l}\text { Hobolt and } \\
\text { Tilley (2016) }\end{array}$ & $\begin{array}{l}\text { European Election Study } \\
\text { data on personal economic } \\
\text { challenge, attitudes } \\
\text { toward immigration/EU } \\
\text { integration, political } \\
\text { affiliation. Focus on people } \\
\text { who switched from } \\
\text { mainstream to challenger } \\
\text { party }\end{array}$ & $\begin{array}{l}\text { Defection from mainstream } \\
\text { to challenger parties and non- } \\
\text { voting }\end{array}$ & $\begin{array}{l}\text { People who experienced economic downturns (decline in } \\
\text { - household income, job loss) more likely to turn away } \\
\text { from mainstream party. Immigration/EU } \\
\text { integration/redistribution preferences tended to } \\
\text { influence which parties people switched to }\end{array}$ & $\begin{array}{l}17 \text { Western } \\
\text { European countries, } \\
\text { Individual, } 2014\end{array}$ & $\begin{array}{l}\text { Multinomial } \\
\text { logit }\end{array}$ \\
\hline Im et al. (2019) & $\begin{array}{l}\text { Risk of automation at } \\
\text { occupational level (per } \\
\text { Arntz et al. 2016) }\end{array}$ & $\begin{array}{l}\text { Vote share for populist } \\
\text { parties in last election (ESS } \\
\text { data) }\end{array}$ & $\begin{array}{l}\text { Individuals "just about managing" on current income are } \\
\text { generally significantly driven toward radical-right voting } \\
\text { by increasing threat of automation. Effect is not observed } \\
\text { for those who already find it difficult or very difficult to } \\
\text { live on their current income. }\end{array}$ & $\begin{array}{l}11 \text { Western } \\
\text { European countries, } \\
\text { Individual, 2012- } \\
2016 \text { (ESS rounds 6- } \\
\text { 8) }\end{array}$ & $\begin{array}{l}\text { Multinomial } \\
\text { logit }\end{array}$ \\
\hline
\end{tabular}


Table 6: Economic insecurity

\begin{tabular}{|c|c|c|c|c|c|}
\hline Reference & Key independent variable & Dependent variable & Main finding & Setting & Estimation \\
\hline $\begin{array}{l}\text { Iversen et al. } \\
(2017)\end{array}$ & $\begin{array}{l}\text { Vulnerability to losing out } \\
\text { from the shift to } \\
\text { "knowledge economy," } \\
\text { based on demographic } \\
\text { variables and quasi- } \\
\text { random variation from } \\
\text { education policy changes }\end{array}$ & $\begin{array}{l}\text { Populist values, based on } \\
\text { WVS and ESS }\end{array}$ & $\begin{array}{l}\text { Support for populist values associated with being a low- } \\
\text { income male; decreases in years of schooling }\end{array}$ & $\begin{array}{l}16 \text { developed } \\
\text { countries, Individual, } \\
1995-2012\end{array}$ & $\begin{array}{l}\text { OLS, IV (for } \\
\text { education } \\
\text { policy change } \\
\text { analysis) }\end{array}$ \\
\hline Rothwell (2016) & $\begin{array}{l}\text { Immigrant share, income, } \\
\text { employment, } \\
\text { demographics, etc. -- big } \\
\text { horse race regression } \\
\text { drawing on Gallup } \\
\text { variables }\end{array}$ & $\begin{array}{l}\text { Favorable view of Trump } \\
\text { (Gallup data) }\end{array}$ & $\begin{array}{l}\text { No clear story emerges--Trump voters tend to live in } \\
\text { racially and culturally isolated zip codes and CZs, but } \\
\text { unclear if material well-being or financial variables such } \\
\text { as trade exposure play a role }\end{array}$ & $\begin{array}{l}\text { U.S., Individual/CZ, } \\
2016\end{array}$ & Probit \\
\hline
\end{tabular}


Table 7: Culture \& identity

\begin{tabular}{|c|c|c|c|c|c|}
\hline Reference & Key independent variable & Dependent variable & Main finding & Setting & Estimation \\
\hline Enke (2019) & $\begin{array}{l}\text { Universalist vs communal } \\
\text { moral values, via nationally } \\
\text { representative survey and } \\
\text { MFQ data; moral content } \\
\text { of politician speeches }\end{array}$ & $\begin{array}{l}\text { Trump vote share (also } \\
\text { examines Trump's supply of } \\
\text { moral language relative to } \\
\text { other candidates, voting for } \\
\text { Trump relative to other GOP } \\
\text { candidates) }\end{array}$ & $\begin{array}{l}\text { Vote share of politicians (esp Donald Trump) matches the } \\
\text { moral values of the electorate--more communal people } \\
\text { tended to vote for Trump }\end{array}$ & $\begin{array}{l}\text { U.S., Individual, } \\
\text { county, 2008-2018 }\end{array}$ & OLS, IV \\
\hline $\begin{array}{l}\text { Gidron and Hall } \\
\text { (2017) }\end{array}$ & $\begin{array}{l}\text { Subjective social status } \\
\text { (based on International } \\
\text { Social Survey Program -- } \\
\text { ISSP) }\end{array}$ & $\begin{array}{l}\text { Support for parties of } \\
\text { populist right }\end{array}$ & $\begin{array}{l}\text { Lower levels of subjective social status associated with } \\
\text { support for right-wing populist parties }\end{array}$ & $\begin{array}{l}20 \text { developed } \\
\text { democracies, } \\
\text { Individual, } 2009 \\
\text { (primarily) }\end{array}$ & OLS \\
\hline $\begin{array}{l}\text { Inglehart and } \\
\text { Norris (2016); } \\
\text { Norris and } \\
\text { Inglehart } \\
\text { (2019) }\end{array}$ & $\begin{array}{l}\text { Many demographic and } \\
\text { economic variables from } \\
\text { ESS (age, sex, employment, } \\
\text { job sector, cultural values, } \\
\text { etc.) }\end{array}$ & $\begin{array}{l}\text { Voted for populist party in } \\
\text { previous national election } \\
\text { (dummy) }\end{array}$ & $\begin{array}{l}\text { Cultural values are consistently statistically significant } \\
\text { predictors of populist voting, while economic indicators } \\
\text { are not }\end{array}$ & $\begin{array}{l}31 \text { European } \\
\text { countries, Individual, } \\
2002-2014\end{array}$ & $\begin{array}{l}\text { Logistic } \\
\text { regression }\end{array}$ \\
\hline Kurer (2020) & $\begin{array}{l}\text { Employment transitions of } \\
\text { workers who perform } \\
\text { routine tasks }\end{array}$ & $\begin{array}{l}\text { Voting intentions of } \\
\text { individuals in panel }\end{array}$ & $\begin{array}{l}\text { Relative to survivors in routine jobs, workers who move } \\
\text { from routine work to unemployment reduce support for } \\
\text { right-wing populist parties, which author interprets as } \\
\text { evidence for social status anxiety rather than economic } \\
\text { insecurity }\end{array}$ & $\begin{array}{l}\text { Germany, } \\
\text { Switzerland, and } \\
\text { U.K., individual, } \\
\text { since 1980s }\end{array}$ & $\begin{array}{l}\text { Marginal } \\
\text { structural } \\
\text { models } \\
\text { (MSM) }\end{array}$ \\
\hline Mutz (2018) & $\begin{array}{l}\text { Perceived status threat of } \\
\text { historical high-status } \\
\text { groups, perceived distance } \\
\text { from both candidates } \\
\text { (using representative } \\
\text { panel survey conducted in } \\
2012 \text { and 2016) }\end{array}$ & $\begin{array}{l}\text { Vote choice (Clinton or } \\
\text { Trump), feelings } \\
\text { thermometer toward parties }\end{array}$ & $\begin{array}{l}\text { Trump voting best accounted for by the movement of the } \\
\text { Democratic candidate away from the average American-- } \\
\text { especially on trade. Perceived status threat strong } \\
\text { predictor of supporting Trump }\end{array}$ & $\begin{array}{l}\text { U.S., Individual, } 2012 \\
\text { and } 2016\end{array}$ & $\begin{array}{l}\text { OLS/logistic } \\
\text { regression in } \\
\text { panel with } \\
\text { fixed effects }\end{array}$ \\
\hline $\begin{array}{l}\text { Sides, Tesler, } \\
\text { and Vavreck } \\
(2018)\end{array}$ & $\begin{array}{l}\text { Attitudes towards racial } \\
\text { inequality and illegal } \\
\text { immigration (from ANES) }\end{array}$ & $\begin{array}{l}\text { Vote for Trump/Republican } \\
\text { candidate in presidental } \\
\text { election }\end{array}$ & $\begin{array}{l}\text { Attitudes towards racial inequality and illegal immigration } \\
\text { drove the vote towards Trump in } 2016 \text { eleciton; there is } \\
\text { little evidence that economic anxiety is associated with } \\
\text { the Trump vote. }\end{array}$ & $\begin{array}{l}\text { U.S., Individual, } 2012 \\
\text { and } 2016 \text { (primarily) }\end{array}$ & $\begin{array}{l}\text { Logistic } \\
\text { regression }\end{array}$ \\
\hline
\end{tabular}

